\title{
Anchoring the Appearance of the Sacred: the Abbot of Choisy \& His Translation of the Imitatio Christi (1692)
}

\author{
Lars Cyril Nørgaard
}

Within the history of the book, the Imitatio Christi holds a place of prominence. In the early modern period, its success was enormous,, ${ }^{* 1}$ even though the work had been composed with a limited readership in mind. As four separate manuscripts, it first circulated within the communities of the Devotio moderna. Quickly disseminated beyond this community of readers, vernacular translations point to a broadening of its audience, and dedications in early printed editions explicitly evoke worldly readers. ${ }^{2}$ The four disparate texts were intentionally transformed into a book. ${ }^{3}$ In this process, the manuscripts became

* The research presented in this chapter is part of my research project on Mme de Maintenon, funded by the Independent Research Fund Denmark and carried out in association with Imems, Durham University, and the Centre for Privacy Studies, housed at the Faculty of Theology, University of Copenhagen. I owe special thanks to emeritus prof. Richard Maber, Durham University, and to prof. Mette Birkedal Bruun, University of Copenhagen. Thanks are due also to Lee Palmer Wandel, Walter Melion and Elizabeth Pastan as well as the participants of the conference Quid est sacramentum.

1 The 16th century saw more than three hundred editions published, while the number in the 17 th century was in an excess of eight hundred. The increase in number of editions peaked in the 18th century, when one thousand one hundred editions were made. In comparison,

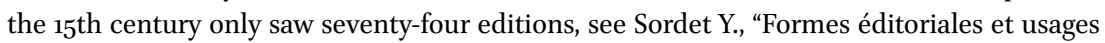
de L'Imitatio Christi, $\mathrm{XV}^{\mathrm{e}}$-XIX ${ }^{\mathrm{e}}$ siècles", Comptes rendus des séances de l'Académie des inscriptions et belles-lettres 2 (2012) 869-95 (871). In terms of the actual number of prints, a conservative estimate comes to 2,3 million prints, while a maximum of 15 million printed copies may have circulated in Europe between the 15th and 19th centuries, cf. Sordet, "Formes éditoriales et usages de L'Imitatio Christi" 872; Barbier F., "Quelque observations sur les origines d'un succès européen", in Delaveau M. - Sordet Y. (eds.), Édition et diffusion de l'imitation de Jésus-Christ (1470-1800), Études et catalogue collectif (Paris: 2011) 35-51.

2 The merging of lay and monastic piety was a salient feature of the reform movement founded by Geert Groote (1340-1384) and known as the Devotio moderna. Translating works into the vernacular was one important vehicle to realize such mergers, see, e.g., Von Habsburg M., Catholic and Protestant Translations of the Imitatio Christi 1425-1650 (Farnham - Burlington: 2011) $31-48$.

3 Identified by the titles of their first chapters, these four parts became known as Admonitiones ad spiritualem vitam utiles ('Helpful counsels for the spiritual life'), Admonitiones ad interna 
equipped with paratextual devices such as chapters with titles, sections within these chapters and the unifying name of an author. ${ }^{4}$ Instead of texts copied individually and compiled in a multitude of ways, ${ }^{5}$ the dispositive of the book was imposed upon the written words. The paratextual devices on the printed page support this abstract ordering: they present words and sentences as part of an argumentative whole and thereby guide the process of reading. As an almost fixed feature of this paratextual system, early modern editions also include a number of images. A frontispiece opens a gateway into the Imitatio, while an image prefaces each of its four books negotiating the transition from one part of the book to the next. In its own right, the frontispiece prompts the reader's reflection on the action of reading, while the four plates, from within the Imitatio, affirm the specific theme of its respective parts. This paper explores the iconographical programme of these prefatory images, which, on different levels and in specific situations, make the sacred mystery appear.

trahentes ('Counsels for the interior life'), De interna consolatione ('On Interior Consolation') and Devota exhortatio ad sacram communionem ('Devout Exhortation to Holy Communion').

4 In the 16th century, the German-speaking and Habsburg Netherlands seem to have attributed authorship to Thomas à Kempis, while Jean Gerson was held to be the author in the Kingdoms of France, Castile and Aragon, and on the Italian peninsula. Other contenders for the title included Bernard of Clairvaux (1090-1153) and Ludolph of Saxony († 1378). In the $17_{\text {th }}$ century, the Benedictines added another possible name to the list: the unknown Italian Giovanni Gersen, who, allegedly, had been abbot of St Étienne at Verceil in the first part of the 13th century. Although 'Gersoncito' had initially been the Society's official title for the work, the Jesuits reacted to the Benedictine claim and came out in full support of Thomas à Kempis. For an overview, see Von Habsburg M., "Short Title Catalogue of all Latin and Vernacular editions of the Imitatio Christi, c. 1470-1650", in Catholic and Protestant Translations of the Imitatio Christi 255-307.

5 Before the explosion of printed editions, we know of almost nine hundred manuscripts, mostly in Latin and dating from the period between 1424 and the 16th century; close to eight hundred of these manuscripts antedate 160o, cf. Axters S., De Imitatione Christi: Een handschrifteninventaris bij het vijfhonderdste verjaren van Thomas Hemerken van Kenpen (Kempen-Niederrheim: 1971); Neddermeyer U., "Redix Studii et Speculum votae. Verbreitung und Rezeption der Imitatio Christi in Handschriften und Drucken bis zur Reformation", in Helmrath J. - Müller H. (eds.), Studien zum 15. Jahrhundert. Festschrift für Erich Meuthen, 2 vols. (Munich: 1994-1995) vol. 1, 457-481. These early copies rarely comprise all four books, because, originally, they were not an organic whole. Indeed, three manuscripts were often bound together and given the title De Musica Ecclesiastica. In these compilations, the fourth book is not part of the 'work'. In other instances, the third and fourth manuscripts switch places: this is the case for the so-called Codex Kempensis, dated to 1441 and in the autograph of the author. On this manuscript, see Delaissé L., Le manuscript autographe de Thomas a Kempis et l'imitation de J.-C.: examen archéologique et édition diplomatique du Bruxellensis 5855-61, 2 vols. (Brussels: 1956). Marginal additions in this important manuscript point to a composite process of writing and rewriting. Here, we should recall the Devotio moderna's technique of spiritual notetaking - the rapiaria - that constituted a fluid reworking of texts. 
In the following, we shall analyse the images that accompany the translation of the Imitatio, carried out by François-Timoléon de Choisy (1644-1724) in the spring of $1692 .{ }^{6}$ This translation contains six images. As a special feature, Choisy's "Epître" includes an anonymous engraving that portrays Louis XIV attending Mass [Fig. 13.1].7 This image of the royal dedicatee serves the purpose of personalizing the translation, but, as we shall see, it also echoes Choisy's "Epître" and its vision of sacred rulership. Furthermore, the depiction of Louis XIV attending Mass [Fig. 13.1] can be connected to the frontispiece [Fig. 13.2], to Saint Arsenius fleeing court [Fig. 13.3] and to Saint Louis receiving the Last Rites [Fig. 13.6]. Together, these four images present the mystery of the king's body and its imitation of the transcendent humility of Christ: this paradoxical mystery culminates in the visual treatment of the Eucharist [Fig. 13.1 and Fig. 13.6].

A second mystery surrounds the depiction of Mme de Maintenon in the Church of Saint-Cyr [Fig. 13.4]. ${ }^{8}$ Abraham-Nicolas Amelot de La Houssaye (1634-1706) suggested that we extend the biblical inscription in this image ('Audi filia', Ps 44.11 / 'Hear, O daughter', Ps 45.10), and thereby integrate 'the king will desire your beauty' (Ps 45.10-11) into our interpretation. Amelot also claimed that this plate and its depiction of Maintenon had caused courtly scandal. For this reason, it had supposedly been removed from the second

6 De l'imitation de Jésus-Christ. Traduction Nouvelle, trans. François-Timoléon de Choisy (Paris, Antoine Dezallier: 1692) Paris, Bibliothèque National de France (hereafter: BnF) Ms. Rés. 16457. Choisy carried out the translation during the late winter of 1691 and early months of 1692. In January 1692, the abbot consulted his friends on the Latin titles of each chapter, arguing that they rarely describe the content of the chapters; could the translator not change them? Against such alterations, his friends maintained that Choisy should remain true to the traditional titles, while others suggested that he should also consult the manuscripts. According to Choisy, the latter suggestion would amount to an endless task, comparable to trying to drink the oceans, cf. 'Journal de l'assemblée de Luxembourg' Paris, BnF (Arsenal), Ms. 3186 , fols. $176 \mathrm{v}-177$. Choisy's translation was also debated, when the group gathered five days later, see 'Journal de l'assemblée de Luxembourg' f. 177v-178.

7 Anon., Messe du roi dans la chapelle de 1682 BnF Ms. Va 78e, fol., t. 7, cf. Maral A., "Létonnante destinée d'un édifice provisoire: la chapelle royale de Versailles entre 1682 et 1710", Bulletin du Centre de recherche du château de Versailles (https://journals.openedition.org/ crcv/11452\#ftn 47 ).

8 In late 1683, Louis secretly married Françoise d'Aubigné, the marquise de Maintenon (16351719). Together, the royal couple founded La Maison Royale de Saint Louis (1686-1793), located at Saint-Cyr just 5 kilometres southeast of the gates of Versailles. In its initial phase, this community consisted of thirty-six Ladies of Saint Louis. Together with a small number of novices and postulants, these Ladies educated two hundred and fifty 'demoiselles' from the lesser nobility, who, on entrance, had to prove noble lineage for a minimum of four generations. Their families also had to have supported the king in his war efforts. In return, the king paid for their education and eventual dowry. 


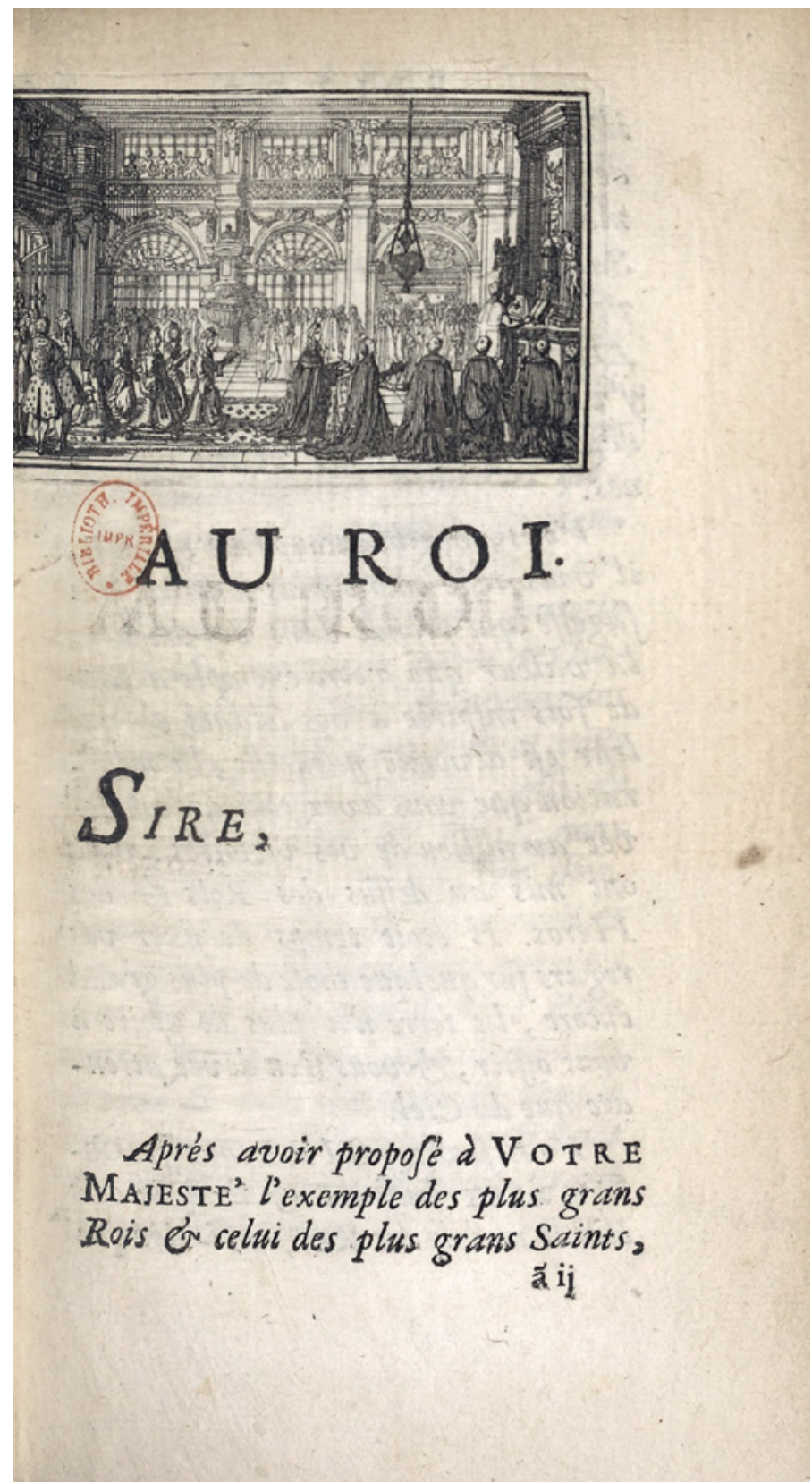

FIGURE 13.1 Anonymous, "Louis XIV Attending Mass", vignette to François-Timoléon de Choisy's "Epître" in De l'imitation de Jésus-Christ. Traduction Nouvelle, trans. François-Timoléon de Choisy (Paris, Antoine Dezallier: 1692)

(C) BNF MS. D-16457, UNPAG 


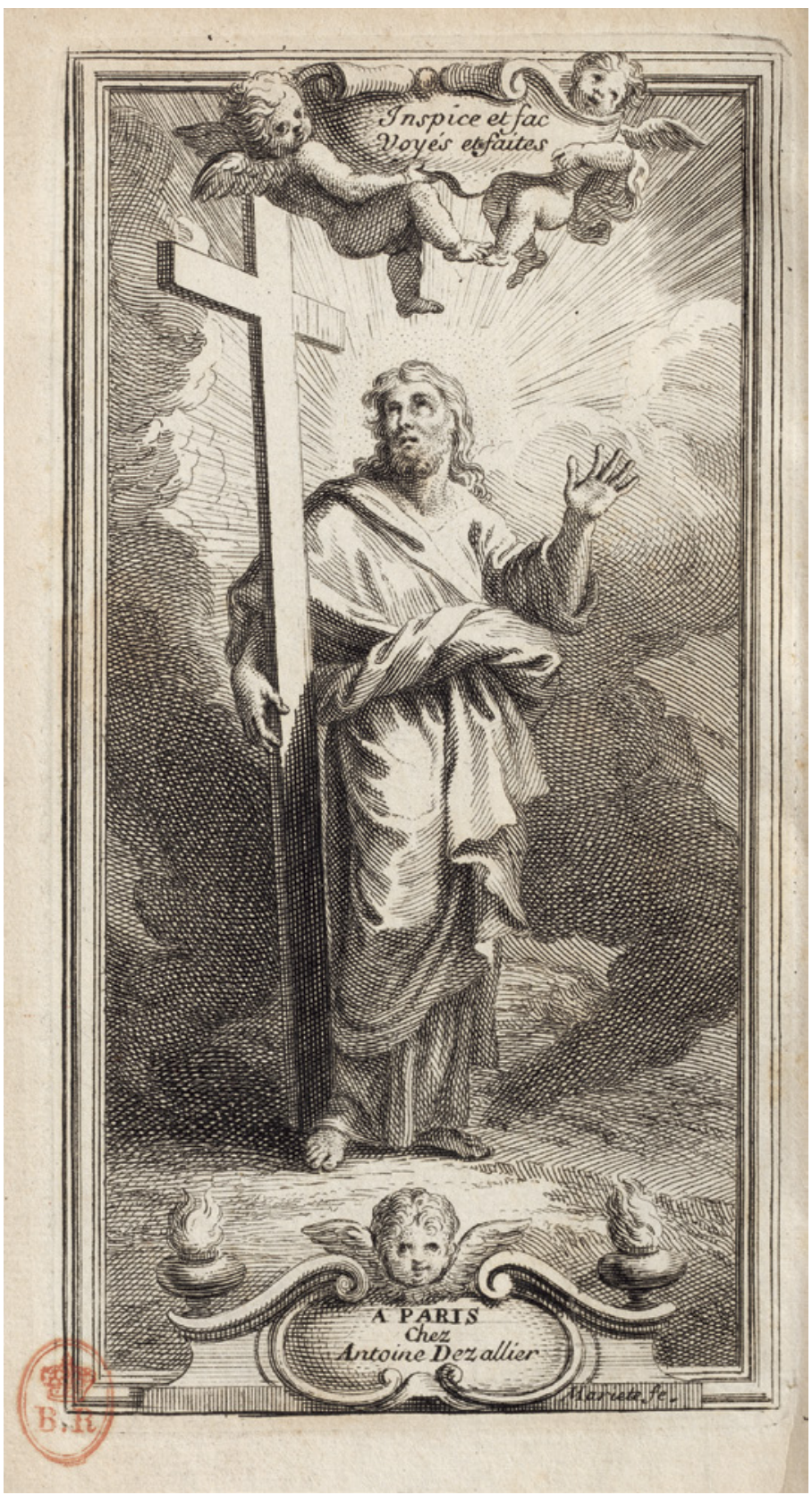

FIgURE 13.2 Mariette, "The Cross", frontispiece to De l'imitation de Jésus-Christ. Traduction Nouvelle, trans. François-Timoléon de Choisy (Paris, Antoine Dezallier: 1692)

(c) BNF MS. D-16459, UNPAG 


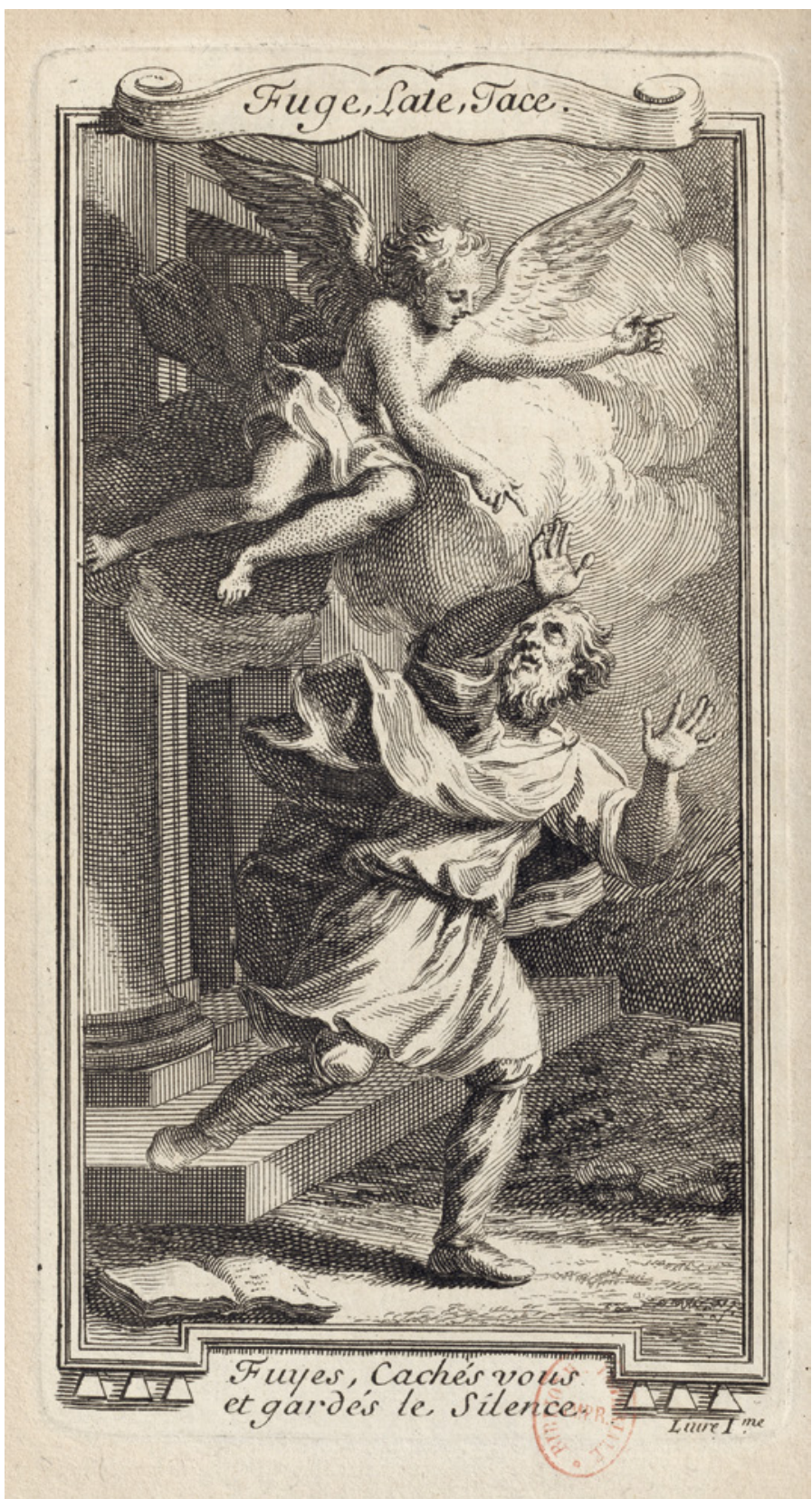

FIGURE 13.3 [Mariette], "Saint Arsenius Fleeing Court", frontispiece to Book I, De l'imitation de Jésus-Christ. Traduction Nouvelle, trans. François-Timoléon de Choisy (Paris, Antoine Dezallier: 1692)

(C) BNF MS. D-16457, UNPAG 
edition of Choisy's translation. ${ }^{9}$ Amelot's claim, however, seems difficult to corroborate. The secret marriage between Louis XIV and Mme de Maintenon surely bewildered courtiers, and this bewilderment prompted confusion and rumours. Besides Amelot, no other contemporary, however, mentions that controversy arose after Choisy published his translation. Nevertheless, this claim was subsequently repeated, ${ }^{10}$ although the depiction of Maintenon was not replaced before the fourth edition of Choisy's translation. ${ }^{11}$ It is thus safe to say that the removal of the depiction of Mme de Maintenon in the Church of Saint-Cyr [Fig. 13.4] was no quick response: it took six years before the plate was removed. Furthermore, the eventual removal was part of an overall reworking of the visual programme which Nicolas II Pitau (1670-1724) carried out. ${ }^{12}$ Instead of repeating Amelot's claim to courtly controversy, ${ }^{13}$ this paper suggests a different interpretation. Two black curtains visually connect the depiction of Mme de Maintenon in the Church of Saint-Cyr [Fig. 13.4] and the depiction of Christ in the home of Mary and Martha [Fig. 13.5]. Below, we shall return to this connection and the apparent unity of these two scenes, where female figures [Figs. 13.4-13.5] interact with the divine Word and visualize the sacred mystery as an interior mode of listening.

9 La Houssaye Amelot de, Mémoires historiques, politiques, critiques et littéraires, 2 vols. (Amsterdam, Michel Charles Le Cène: 1724 [1722]) vol. 2, 84-85.

10 Thoulier Pierre-Joseph, La vie de Monsieur de l'abbé de Choisy de l'Académie française (Lausanne-Genève, Bousquet: 1742) 166-167; Angliviel de La Beaumelle Laurent, Mémoires pour servir à l'histoire de Madame de Maintenon et à celle du siècle passé, followed by the Lettres de Madame de Maintenon, 15 vols. (Amsterdam, Aux dépens de l'auteur: 1755-1756) vol. 3 (1756), 70 .

11 De l'imitation de Jésus-Christ. Traduction Nouvelle. Dediée au roi, trans. François-Timoléon de Choisy (Paris, Antoine Dezallier: ${ }^{4}$ 1699). Already Barbier noted Amelot's mistake and speculative suggestions, cf. Barbier A.-A., Dictionnaire des ouvrages anonymes et pseudonymes, 4 vols. (Paris: 1806-1809) vol. 1 (1806), 896-899; idem., Dissertation sur soixante traductions françaises de l'imitation de Jésus-Christ (Paris: 1812) 49-51.

12 Pitau removed the architectural structure from which Saint Arsenius runs away [Fig. 13.3]. As a visual threshold to the second book, Pitau inserted a male figure in prayer. In an interior setting, he kneels down in front of a prie-dieu, where open books rest: above the male figure, a heavenly light breaks through a dark cloud formation and makes appear a verse from $P s$ 30: 'Seigneur, je crierai vers vous et vous adresserai ma priere' ('To You, Lord, I cried, and to You I made my supplication', Ps. 30.8). Prefacing the third book [Fig. 13.5], Pitau placed Mary and Jesus in an open courtyard with pillars in the background: Martha completely disappears in this image. The final representation of Saint Louis is moved from the camp in Tunis to an interior setting [Fig. 13.6].

13 The claim is repeated in, e.g., Preyat F., Le Petit Concile de Bossuet et la christianisation des mours et des pratiques littéraires sous Louis XIV (Berlin: 2007) 145; Meyer V., "Suites et cycles: les éditions illustrées de l'Imitation de Jésus-Christ au XVII ${ }^{\mathbf{e}}$ siècle", in Delaveau Sordet (eds.), Édition et diffusion de l'imitation de Jésus-Christ (1470-180o), 53-70 (64). 


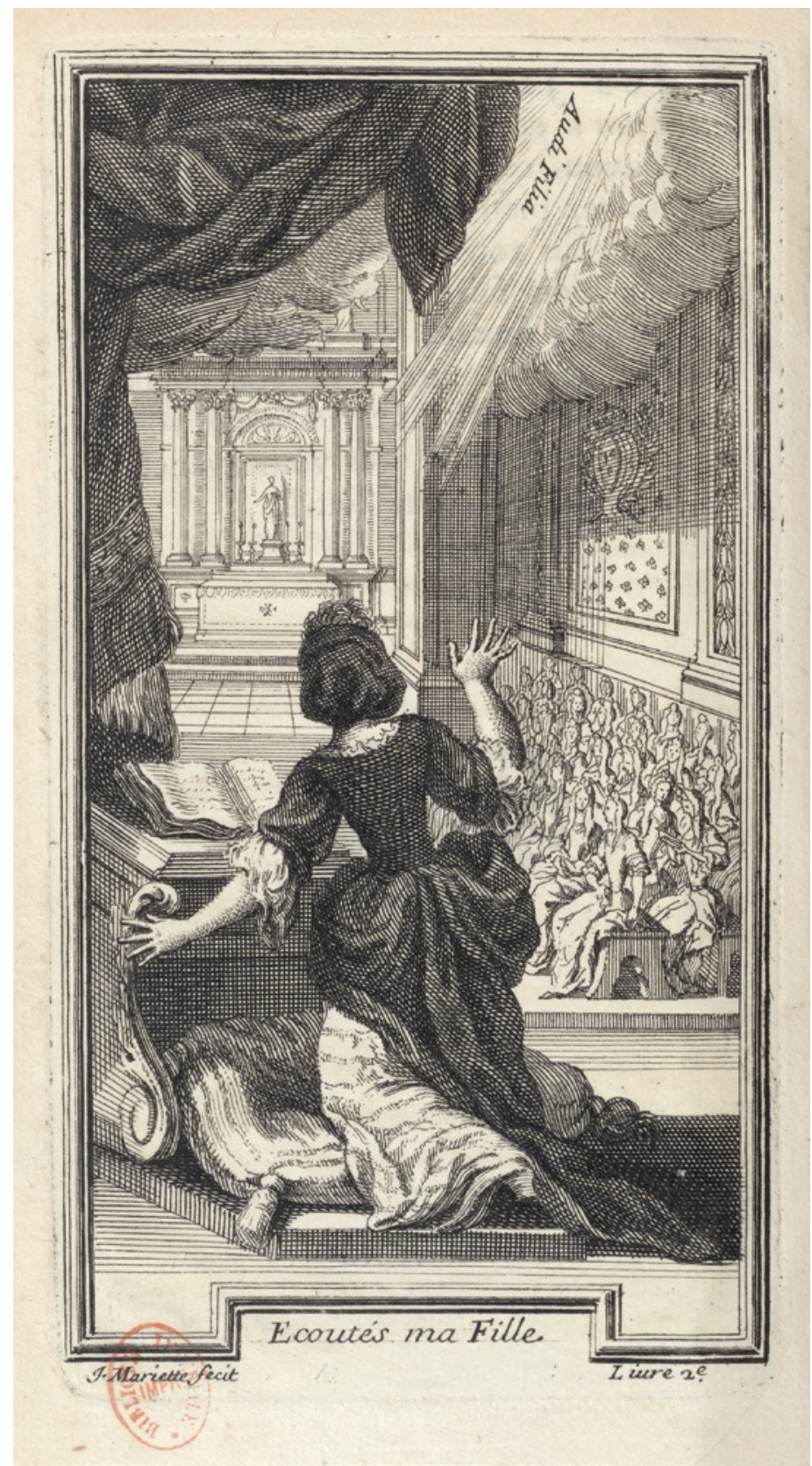

FIGURE 13.4 Mariette, "Mme de Maintenon in the Church of SaintCyr", frontispiece to Book II, De l'imitation de Jésus-Christ. Traduction Nouvelle, trans. François-Timoléon de Choisy (Paris, Antoine Dezallier: 1692)

(C) BNF MS. D- 16457 , P. $70 \mathrm{~V}$ 


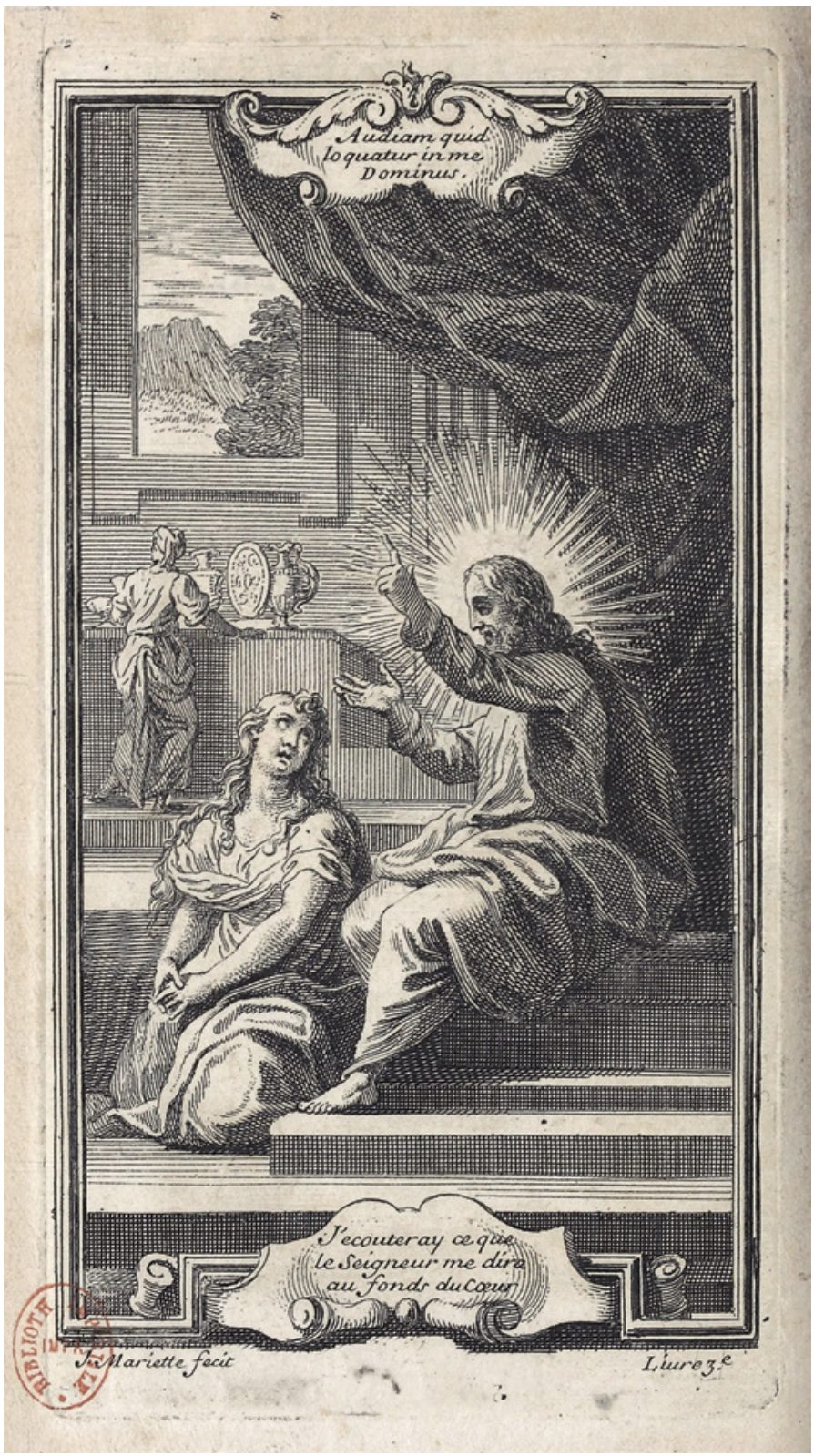

FIGURE 13.5 Mariette, "Christ in the Home of Mary and Martha", frontispiece to Book III, in De l'imitation de Jésus-Christ. Traduction Nouvelle, trans. François-Timoléon de Choisy (Paris, Antoine Dezallier: 1692)

(C) BNF MS. D-16457 (BETWEEN P. 110 AND P. 111) 
Today, the Abbot of Choisy is best known for his adventures in cross-dressing and in drag. ${ }^{14}$ The Journal du voyage de Siam has also attracted scholarly attention. In December 1684, while Choisy was preparing himself for a life within the Congrégation de Missions Etrangères at the Rue du Bac in Paris, ${ }^{15}$ he caught wind that volunteers were needed for a royal mission to present-day Thailand. By authoring a number of texts that detailed how to rebuild and reorganize the French embassy, the abbot positioned himself as a liaison between members of the religious community and the court at Versailles. With Choisy on board, the ships set sail on 1 March 1685. Shortly after their return in June 1686, Choisy published his travel narrative, ${ }^{16}$ followed by two historical portraits of biblical kings: first, La vie de David appeared alongside an interpretation of the Psalms, ${ }^{17}$ and second, La vie de Salomon. ${ }^{18}$ Together with the popularity of the Journal, these portraits secured Choisy, on 25 August 1687, membership

14 Choisy François-Timoléon de, "Mémoires de l'abbé de Choisy habillé en femme", in Mémoires de l'abbé de Choisy, ed. G. Mongrédien (Paris: 1966) 429-522 (Paris, BnF (Arsenal), Ms. 3188, f. 1-51). This work comprises a number of texts to which Choisy's nephew, René-Louis de Voyer de Paulmy (1694-1757), added the unifying title "Avantures de l'abbé de Choisy, habillé en femme", Ms. 3188, f. 1. Paul Scott has argued that no single shred of independent evidence supports what Choisy recounts: the same holds true for the accounts of cross-dressing in Choisy's here Mémoires pour servir à la cour de Louis $X I V$, see Scott P., "Authenticity and Textual Transvestism in the Mémoires of the Abbé de Choisy", French Studies 69 (2014) 14-29. This lack of historical authenticity does not render the accounts untruthful; it is rather a matter of the level upon which we are to understand their truth claims.

15 After finishing his theological studies, Choisy divided his life between the Palais de Luxembourg and longer stays in Rome and Venice. In 1682, the abbot made his permanent return to Paris, but the following year he fell seriously ill. Surviving this near-death experience, Choisy's lukewarm religious sentiments became increasingly fervent, and the instalment at Rue du Bac was a first manifestation of this change of heart. During the spring of 1684, Choisy and his old friend, Louis de Courcillon (1643-1723), published an account of his conversion: Quatre dialogues. I. Sur l'immortalité de l'Ame, II. Sur l'Existence de Dieu, III. Sur la Providence, IV. Sur la Religion (Paris, Sebastian Mabre-Cramoisy: 1684). For biographical information, I refer to Van der Cruysse D., L'abbé de Choisy. Androgyne et mandarin (Paris: 1995).

16 Choisy François-Timoléon de, Journal du voyage de Siam fait en M.DC.LXXXV et M.DC. LXXXVI (Paris, Sebastian Mabre-Cramoisy: 1687), cf. Van der Cruysse D., Louis XIV et le Siam (Paris: 1991).

17 Choisy François-Timoléon de, Interpretation des Pseaumes, où les differences notables de l'hebreu \& de la Vulgate sont marquées. Avec la vie de David (Paris, Antoine Dezaillier: 1687).

18 Choisy François-Timoléon de, La Vie de Salomon (Paris, Claude Barbin: 1687). 
in the Académie française..$^{19}$ Upon his induction, the abbot launched an ambitious historiographical project. He set out to write the history of the French kings who had ruled from 1328 until 1461. Like his accounts of David and Solomon, Choisy's royal portraits are hardly oblique in their praise of Louis XIV. The first instalment, published in 1688, deals with the reigns of Philip VI (1293-1350) and John the Good (1319-1364), ${ }^{20}$ while the victorious reign of Charles v (1338-1380) was initially planned to appear that same year. However, Choisy had to delay this publication. ${ }^{21}$ For reasons unclear, he diverged from the outlined plan and instead portrayed Louis XIV's most prominent ancestor, Louis IX (1214-1270). ${ }^{22}$ The total of five royal portraits, written between 1688 and 1695, and the portraits of David and Solomon, both written in 1687, correspond with Choisy's translation of the Imitatio. All these publications were dedicated to Louis XIV. ${ }^{23}$ Furthermore, the translation of 1692 shows both Louis XIV and Louis IX: the vignette [Fig. 13.1] in Choisy's "Epître" depicts the kneeling Louis, and the plate that prefaces the fourth book repeats this bodily pose in the figure of Saint Louis [Fig. 13.6]. ${ }^{24}$

19 Discours prononcés à l'Académie français, le 25 août 1687 , à la réception de M. l'abbé de Choisy, par le récipiendaire et M. Bergeret (Paris, Claude Barbin: 1687). Choisy François-Timoléon de, Histories de Philippe de Valois et du roi Jean (Paris, Claude Barbin: 1688).

21 It was published the following year: Choisy François-Timoléon de, Histoire de Charles cinquième, roi de France (Paris, Antoine Dezaillier: 1689). The public had to wait even longer for the final installation in Choisy's project: Choisy François-Timoléon de, Historie de Charles VI, Roi de France (Paris, J.-B. Coignard: 1695).

22 Choisy François-Timoléon de, Vie de Saint Louis (Paris, Claude Barbin: 1689). In his dedication to La vie de Saint Louis, Choisy connects this work with his previous publications, collectively defined as 'les Histoires'. The successful reigns of the biblical kings and the failed reigns of Philip the Fortunate and John the Good are said to overlap in the life of Louis Ix: like David and Salomon, the Saint-King saw victory in France, while his defeat under foreign skies is similar to what past French kings suffered at home, cf. Choisy, Vie de Saint Louis Unpag. [1-2].

23 In total, Choisy addresses Louis XIV in eight dedications; Van der Cruysse D., "Labbé de Choisy et le mythe louis-quatorzien", in De Branche en Branche. Études sur le XVII e et le XVIII ${ }^{e}$ siècles français, La République des lettres 26 (Louvain: 2005) 213-23.

24 A similar overlap is detectable in Choisy's written accounts: these texts cast the king in the mould of past rulers and make visible different aspects of sacred kingship. In the figure of Solomon, the abbot invites the king to see that this biblical king made his enemies tremble: the present ruler and his glory in war are hereby made visible. This mirroring should also make Louis XIV see Solomon trembling before the living God; Choisy, La Vie de Salomon Unpag. [3-4]. In his preface to the life of Charles v, Choisy underlines this point: 'It is almost impossible to study the history of kings and heroes, without constantly seeing the image of Your Majesty' ('Il est presque impossible de travailler à l'Histoire des Rois \& des Heros, qu'on ne voie sans cesse l'image de VOTRE MAJESTE'), Choisy, Histoire de Charles cinquième Unpag. [1-2]. The written portrait of the monarch thus refers itself 


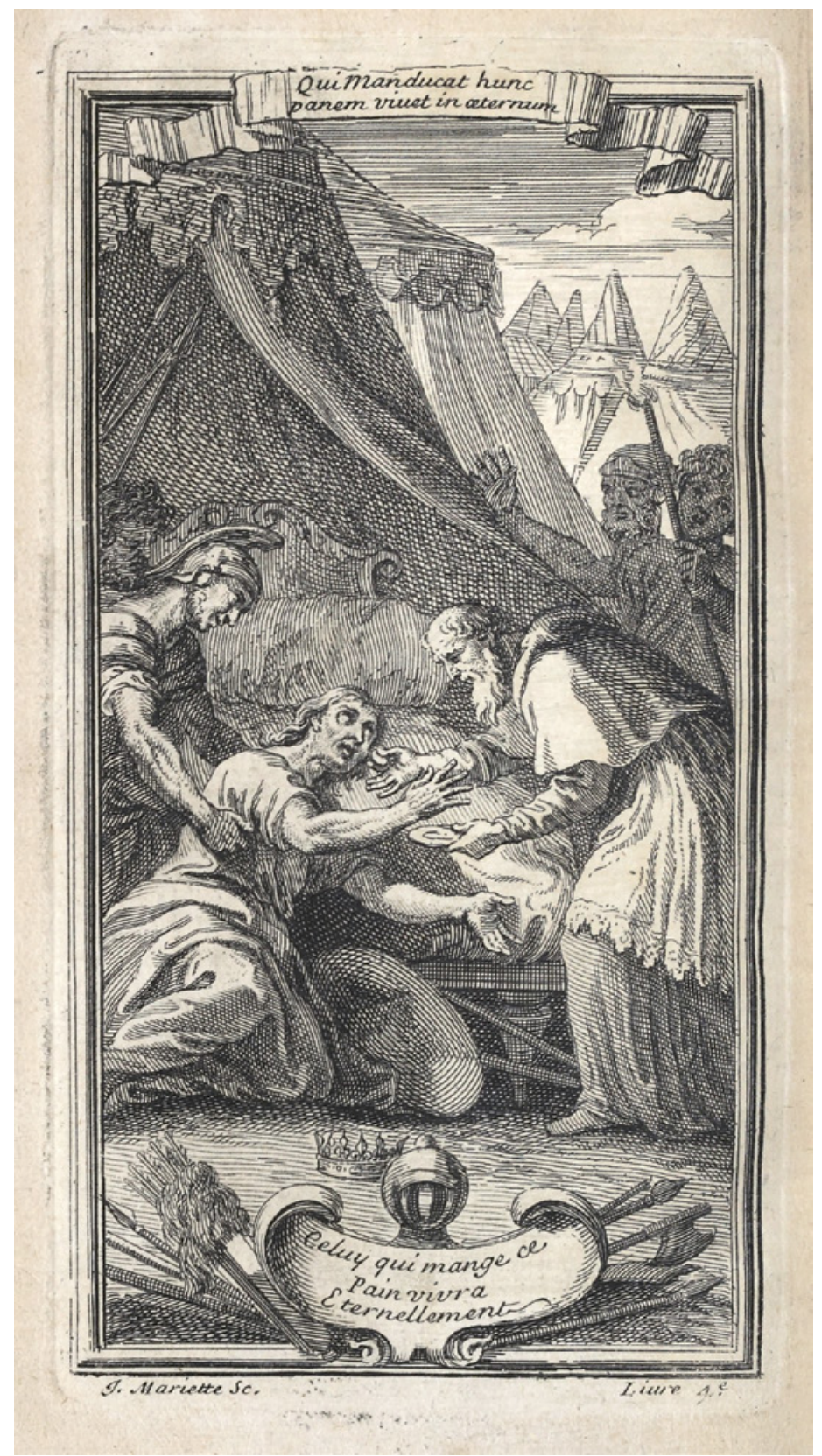

FIGURE 13.6 Mariette, "Saint Louis Receiving the Last Rites", frontispiece to Book IV, De l'imitation de Jésus-Christ. Traduction Nouvelle, trans. François-Timoléon de Choisy (Paris, Antoine Dezallier: 1692)

(C) BNF MS. D-16457 (BETWEEN P. 272 AND P. 273) 
In fact, Choisy presents his translation of the Imitatio as a culmination of the previous portraits: 'Sire, after having proposed to Your Majesty the example of the greatest kings and Saints, nothing remains but for me to place before your eyes Jesus Christ himself, the king of kings and the Saint of Saints' ('Sire, après avoir proposé à VOTRE MAJESTÉ l'exemple des plus grans Rois \& celui des plus grans Saints, il ne me restoit plus qu'à vous mettre devant les yeux JESUS-CHRIST même, le Roi des Rois \& le Saint des Saints'). ${ }^{25}$ The Imitatio makes Christ appear, and the act of reading thus amounts to having something placed before the eyes. More specifically, as Choisy puts it: 'In the book that I present to you, his ethics, in all its divinity, can be found diffused across all of the pages, and there [in the book] you will everywhere see the emptiness of human greatness and even of human virtues' ('Sa morale toute divine se trouve répanduë dans toutes les pages du Livre que je vous presente, \& vous y verrez par tout le néant des grandeurs, \& même des vertus humaines'). ${ }^{26}$ The appearance of the divine - that is, true humanity as expressed in the life of Christ - renders void everything that belongs to the terrestrial world. Unlike the royal portraits and their mirroring of the present ruler, the image of Christ, as presented by the Imitatio, breaks the frame of social reality: it invites the king to see an emptiness where others recognize greatness and virtuous acts. Lending something to the eyes, the appearance of Christ invites the dedicatee to change his outlook on the world.

\section{The Kneeling Figure of Louis XIV}

Alongside this general presentation, Choisy states that the king, paradoxically, is as grand in times of defeat as in times of triumph. ${ }^{27}$ Indeed, the Nine Years War (1688-1697) caused an important shift in royal ideology: the experience of political isolation prompted a new symbolic framework for representing authority. ${ }^{28}$ In Choisy's words, the nations that join forces against France do

to an iconic semblance between past and present, cf. Marin L., Le portrait du roi (Paris: 1981) 49-109.

25 Choisy, "Epître" Unpag. [1-2].

26 Choisy, "Epître" Unpag. [2].

27 Choisy, "Epître" Unpag. [3].

28 This change is noticed by, e.g., Apostolidès J.-M., Le Roi-machine: spectacle et politique au temps de Louis XIV (Paris: 1981) 114-131 (128-31) and Burke P., The Fabrication of Louis XIV (New Haven - London: 1992) 126-133. More specifically, the late 1680 and early $1690 \mathrm{~s}$ saw an increasing effort to cast the king in the mould of Saint Louis, see, e.g., Gouzi C., "Louis XIV en Saint Louis: une autre image de la figure royale", in Da Vinha M. - Maral A. Milovanovic N. (eds.), Louis XIV l'image et le mythe (Rennes: 2014) 57-70. The foundation 
nothing but excite her people's love for their king, while also demonstrating the inexhaustible might of her military. ${ }^{29}$ Europe has gone blind or turned raving mad, Choisy laments, but yet Louis still wins battles and secures territory. Accordingly, he can now legitimately call himself the sole defender of God and of the rights of anointed kings.

Isolated from his disciples, falsely accused and made to endure intolerable pain, the suffering Christ is here presented as a model for all men but, specifically, for the king: his Passion is the interpretive key that unlocks the present political predicament. Glorifying the image of Louis XIV, Choisy not so much blindly praises the king as he fleshes out a royal ideology of humility, sacrifice, and interiority. Indeed, suffering and defeat are proofs that Providence has tested the king. When Louis is publicly humiliated, this is, in fact, a divine course of action whereby God runs a test of royal humility. Why else would God select Louis XIV to add lustre to the throne that was already the most powerful in the world? According to Choisy, it was with the sole intention of making the king fall from the summit of the highest possible peak. ${ }^{30}$ In his steep, precipitous descent, the king's display of humility honours God in a way so perfect that it surpasses the capacities of all other men. No one else can be humiliated in the manner of such a man, placed high above everyone else.

With this in mind, the abbot asks why so many marvels have been accomplished, despite of the entire world having rallied against the crown. Why have France's many enemies not overrun her? Choisy's framework of interpretation insists on the fact that the only credible explanation resides within the king. Humiliated by God, Louis, by remaining humble, has saved the realm from the full extent of divine wrath. Hidden humility, if it is the true reason behind France's surprising success, causes Choisy to ponder, perhaps ironically, whether Louis XIV has gone out of his way to hide this transcendent humility. ${ }^{31}$ The abbot nonetheless maintains that royal humility, whether discernible or not, is what safeguards the realm, and his dedication thus inscribes humility into the heart of authority. ${ }^{32}$ This state is invisible, but Choisy posits it as the

of La Maison Royale de Saint Louis at Saint-Cyr and the order of the Ladies of Saint Louis shared this focus on Saint Louis; see Neveu B., "Du culte de Saint Louis à la glorification de Louis XIV: la maison royale de Saint-Cyr", Journal des savants 3 (1988) 277-29o.

29 Choisy, "Epître" Unpag. [3]. This point is already stated in Choisy's "Epître" to the second edition of his Interpretation des Pseaumes (169o), where the abbot also speaks of a Europe in league against the king.

30 Choisy, "Epître" Unpag. [4-5].

31 Choisy, "Epître" Unpag. [5].

32 For similar ideas about royal humility, see, e.g., Bossuet Jacques-Bénigne, Politique tirée des propres paroles de l'Ecriture sainte à Monseigneur le Dauphin, ed. J. Le Brun (Geneva: 1967 [1709]) Book 7, Article vi, Propositions 1-13, 271-283. On Choisy's ties to Bossuet and 
only credible explanation of the present state of affairs. By implication, political events reveal what cannot readily be observed.

In his "Epître", Choisy distinguishes the king's exterior actions from his interior state that remains invisible. Defeats can be interpreted as part of the divine plan and as tests of royal humility. Unlikely in the face of overwhelming opposition, the king's achievements in battle are incremental signs that Louis has passed God's test. As such, the narration of royal actions refers to a hidden level of reality, tied to the king's person and, as such, not readily perceivable. Keeping these two levels in mind, the king's relationship to the divine is anchored into his interior realm. This mode of interiority is not subject to change in the same way as the king's historical body, making Louis XIV, simultaneously, a mortal man and immortal monarch. If one could enter into the king's interior, Choisy avers, the royal heart would be seen to be humble before God: the sovereign, in his private relation to the king of kings, epitomizes the condition of humility. Indeed, his hidden humility is comparable to the strength and greatness by which Louis stands before his fellow men. ${ }^{33}$ Dialectically, Choisy thus positions the figure of Louis XIV between visible superioritas and hidden humilitas, incorporating these two in the same persona. ${ }^{34}$

However, the abbot of Choisy points to a specific situation in which what is interior to the king is put on display. When the king participates in 'the most majestic of our mysteries' ('le plus auguste de nos mysteres'), his respect for things divine becomes visible. Participation in the Lord's Supper is nothing short of a perpetual testimony to the truth that Louis neither indulges in courtly praise nor blindly believes in glorifying his achievements. ${ }^{35}$ The king instead

the courtly network that gravitated towards him, see Preyat, Le Petit Concile de Bossuet 433-481.

'Permettez nous d'entrer aujourd'hui dans le cœur de votre Majesté \& nous le découvrirons aussi humble, aussi petit devent Dieu, qu'il est fier \& grand devent les hommes.' Choisy, "Epître" Unpag. [3].

34 The study of the French king's mortal body vis-à-vis his immortal body was initiated by Kantorowicz E., The King's Two Bodies: A Study in Mediaeval Political Theology (Princeton: 1957) $195^{-232}$. As stressed by Alain Boureau, the theory of the king's two bodies, as reconstructed by Kantorowicz, makes no simple claim to the sacred nature of the king's person. Rather this theory outlines a "fictional space" wherein the immortality of the political body, rationally, can be elaborated at the intersection of theology and law, see Boureau A., Le Simple corps du roi. L'impossible sacralité des souverains français $-X V^{e}-X V I I I{ }^{e}$ siècle (Paris: 2000) 16-24. Kantorowicz maintained that this fictional space of elaboration was an important step towards the secularization of political rule. We shall return to this point below. 
demonstrates humility whenever he kneels before the altar. ${ }^{36}$ The mystery of the elements - bread and wine transubstantiated - translates to the visible and the hidden aspects of the royal corporality. Choisy thus refers the reader to a liturgical situation, where the corpus mysticum is the Sacrament of the Altar, but, simultaneously, connected to the king as a persona mystica. ${ }^{37}$ The Eucharist's mystical materiality - its incarnational signification between absence and presence, between invisible and visible - is linked to the king's hidden humility and its effect upon events in the visible domain. ${ }^{38}$

Furthermore, Choisy's reference to Louis XIV's liturgical participation points the reader to the anonymous vignette that accompanies his dedicatory statement [Fig. 13.1]. The king kneels beside his royal aumôniers on a liturgical cloth of honour: this scene takes place in the chapel at Versailles, and immediately behind the kneeling king stands a number of figures; their close proximity to the king may suggest that these individuals are 'les enfants de France'. In the left foreground, two male figures are seemingly conversing rather than participating in the liturgical rite. Behind the entire group, faceless courtiers are positioned on the balconies and floor of the chapel: the chancel lamp signals

$3^{6}$ Alexandre Maral details how the 'roi liturgique' was assimilated to the figure of the bishop: certain liturgical deeds, normally reserved for those vested with episcopal authority, were granted to the king, see Maral A., "Portrait Religieux de Louis XIV", Dix-septième siècle 217 (2002/4) 697-723 (698-705).

37 The shift from a sacramental understanding of the corpus mysticum, closely linked to the consecrated Host and specific liturgical situations, to the 'mystical person' is central to what Kantorowicz and his followers call the secularization of the mediaeval Church, cf. Kantorowicz, The King's Two Bodies 197; 201. This historical event, dated to the 12th century, is said to have transported the mystical from liturgical situations to a vocabulary of ecclesiastical and juristic abstraction. To make this argument, Kantorowicz draws on de Lubac H., Corpus mysticum. L'Euchariste et l'Église au Moyen Âge. Étude historique (Paris: 21949). According to Jennifer Rust, Kantorowicz plays down the 'fluid relation between ecclesia and Eucharist' in de Lubac's historical reconstruction: in his outline of a linear process of secularization, Kantorowicz flattens out de Lubac's historical analysis and its claim that "the "liturgical or sacramental" was always already "sociological" in the milieu of the early church'. Rust J., "Political Theologies of the Corpus Mysticum: Schmitt, Kantorowicz, and de Lubac", in Hammill G. - Lupton J. R. (eds.), Political Theology and Early Modernity (Chicago: 2012) 102-123 (114).

38 With regard to Louis xIV, Louis Marin divides royal corporality into three, interconnected bodies: a historical body that is mortal; a juridical, political body that is immortal; a sacramental body, where the mortal and the immortal bodies continually merge, see Marin, Le portrait du roi 7-22 (20-21). According to this hypothesis, the king is not king outside of his sacramental body, where the historical individual is portrayed as outside the realm of history: visual, written or other modes of representing the king thus straddle the difference between physical caducity and institutional continuity, making a mortal man into an eternal monarch. 
the divine presence in the Blessed Sacrament. On display is the appearance of the sacred as this takes place in a recognizable liturgical setting. The vignette, on one level, portrays an event that was part of court life - that is, the king's participation in the celebration of the Mass. ${ }^{39}$ In this very rudimentary sense, the kneeling figure of the king anchors this translation of the Imitatio into a historical setting. However, Choisy's "Epître" calls into question the straightforward reality of the depicted scene. The kneeling king is presented as an historical individual, but also as the embodiment of an invisible state of humility: it is this state that the plate makes visible. The mystical presence of Christ in the Sacrament prompts the king to perform a public act of imitatio that bodies forth interior humility, revealing it to the reader-viewer.

To this interpretation and its interlacing of private and public, Choisy adds that Louis should not see himself in an earthly perspective. This self-image will only support a sense of grandeur and thereby confuse his vision. Instead of indulging in courtly praise, the king should turn his eyes upwards and look towards Christ. In this change of sight line, Louis will see everything that Christ is and, by this light, worldly values will lose their blinding effect. By heavenly standard, all that surrounds a king becomes 'nothing but a feeble image of the eternal: such objects sustain but a flimsy participation in the divine; they are nothing but a shadow of the eternal splendour that belongs to the almighty God' ('toute cette Majesté qui vous environne, n'est qu'une foible image, une lègere participation, une ombre de la splendeur du Tout-puissant').${ }^{40}$ Courtiers and courtly splendour engage the king at his own eye level and glorify his image: this engagement, however, distorts the royal perspective, urging him to believe flattery. Turning his eyes upwards and towards Christ shatters false images and restores perspective. The king will recognize how small he is in the eyes of Christ, moving from aggrandizing gestures to the abasement of self. As mentioned above, Choisy presents the Imitatio as a book which places Christ before the king's eyes: this allows Louis, in turn, to see the emptiness of human greatness and of human virtues. ${ }^{41}$ In this part of his "Epître", Choisy complicates

39 Ignoring the complex genesis of the Mémoires pour l'instruction du dauphin, the king here states that 'les respects publics' which princes render unto the 'puissance invisible' should be considered the most important part of his politics, cf. Louis XIV, Mémoires pour l'instruction du dauphin, ed. P. Goubert (Paris: 1992) 83.

40 Choisy, "Epître" Unpag. [4].

41 Choisy, "Epître" Unpag. [2]. 
our understanding of vision. The state of humility involves a specific kind of looking past earthly matters and fixating the royal gaze upon Christ.

Continuing this line of enquiry, the frontispiece to Choisy's translation shows a male figure with his right arm around the cross [Fig. 13.2]. From the background, a heavenly light shines forth and illuminates the top half of the cross. Breaking through two columns of smoke that rise from the ground, light emanates from a sun-like shape placed behind the male figure's head and serving as his halo. In the shadow of the folds of the man's waistline, the bottom half of the cross remains in shadow. What is here put on display? The anonymous figure? The cross? The entire scene unfolds on a rock formation; above the scene two angles carry a cartouche which reads: 'Inspice et fac / Voyés et faites' ('See and make'). These three words are from the Revelation on Mount Sinai, when God gives Moses precise instructions how the lampstand should be realized (Ex 25.31-40). About the seven lamps on the stand, God exhorts: 'Inspice, et fac secundum exemplar quod tibi in monte monstratum est' ('And see that you make them (the seven lamps) according to the model that is being shown to you on the mountain', Ex 25.40). The smoke appearing in the scene is thus a reference to Mount Sinai, when the Lord descended upon it 'in fire and ascending smoke' (Ex 19.18). The visual representation integrates two burning lamps: they frame the design at the bottom where the place and name of the publishing house are displayed. This design protrudes into the 'frame' and rests on the thin line that separates it from the paper, thus conveying a sense of depth to the entire scene. The male figure stands behind this design but in front of the light breaking through the rising smoke. This substance, simultaneously, serves as a symbolic frame of support and as an obstacle to the viewer, referring to the clouds that always accompany the manifestation of God's glory (e.g. $E x 24.15^{-18}$ or $E x 40.34$ ) and underlining the impossibility of directly seeing this glory ( $E x$ 33.18-23), which, visually, supports the imperative not to make images/idols of God (Deut 5.8).

Who is the male figure? We might be tempted to identify him as Christ. Indeed, Choisy states that the Imitatio makes Christ appear to its royal dedicatee. This identification is made problematic, however, by the representation of Christ in the home of Mary and Martha [Fig. 13.5]. There are clear differences between the two male figures. Still, the frontispiece clearly refers the viewer to Calvary and the supernatural darkness caused by the crucifixion of Jesus ( $M k$ 15.33 and $M t$ 27.45, but cf. $L k$ 23.44-45). Nevertheless, this is neither the revelation of Mount Sinai nor the Crucifixion. It calls forth both these scenes and maps them onto each other, resulting in an imaginary blend: elements from each scene are presented simultaneously, leaving it for the viewer to imagine a new image encompassing both. The elevated peak is therefore not an actual 
place, and the depicted incident is no representation of an event narrated in the biblical text. Evoking the appearance of the sacred, the frontispiece illustrates the title of the book, Imitatio Christi, turning it into a visual instruction for the reader-viewer. The elevated site, near the text's beginning, symbolizes the position of readers about to enter the book. The biblical injunction 'inspice et fac secundum exemplar' relates to the reader-viewers' imitation of Christ their becoming, through reading, an Image of Christ, who, in his own turn, is the Image of God. However, such imitation requires that readers, first, mind the crucified Christ, and the frontispiece presents this requirement by way of an imaginary blend. Simultaneously, the frontispiece presents God's revelation on Mount Sinai and the Crucifixion to its viewers, who are to see a depiction of neither scenes but rather to construe an unforeseen scene. Producing this new image, the turning motion of the anonymous figure's head and the twisting motion of the cross command attention. The divine injunction to inspect is encapsulated by this minute detail: it shows the inspection of the cross as the model that is to be followed; to imitate Christ is to create oneself in his image. Presenting the Imitatio as a book where Christ is put before the dedicatee's eyes, this visibility involves an act of image making, and the frontispiece encapsulates this second dimension. It shows the inspection of the cross, but displaces this scene from the biblical narrative and relocates it to the domain of the reader-viewer. On an immediate level, the visual instruction of the frontispiece demands that the reader-viewer, univocally, focuses on the cross, but this clear instruction, in blending biblical scenes, also prompts the creation of an unforeseen image: the act of inspecting the cross entails imagination - that is, creating oneself in the image of Christ, the true image of God.

\section{5}

\section{Leaving Court}

As Choisy states, the imitation of Christ involves a specific kind of looking past: producing an image of oneself based on this Christological model, terrestrial things turn out to be but a feeble image of the divine. In this connection, the first book in Choisy's translation is prefaced by a depiction of Saint Arsenius († 445) and his flight from court [Fig. 13.3]. In the upper middle, the Latin inscription fuge, late, tace unfolds on a banderol. In the subscription, this motto is rendered in French: 'Fuyes, cachés vous et gardés le silence' ('Flee, hide yourself, and observe silence'). The three Latin words are a condensation of the opening lines in the Saint's life:

One day, while he was still at court, Arsenius asked God in his prayer: 'Lord, teach me what I must do to save myself'. He then heard a voice that 
answered him: 'Arsenius! Flee the company of men, and in this way you will save yourself'. Making the same prayer to God when he was in the desert, he again heard a voice that said unto him: 'Arsenius! Flee men, keep silent, and remain in tranquillity'. These, then, are the most important things that must be done to save oneself. ${ }^{42}$

This stub of text describes two distinct acts of withdrawal from the world. In the first, the saint removes from the court to the desert; in the second, he removes himself from humankind, entering a spiritual as well as a physical isolation. The image, however, conflates these two acts. Saint Arsenius exits the door of an architectural structure, while the banderol, with the imperative to keep silent, also speaks to his second and more complete rupture.

A similar conflation can also be found in Choisy's own account of the Saint's life, which he wrote on the behest of Mme de Maintenon. During 1691, the king's wife commissioned Choisy to write a number of pious stories, intended to assist the Ladies of Saint Louis charged with educating the 'demoiselles' housed at Saint-Cyr. ${ }^{43}$ Maintenon mentions the stories in a letter of 1702 , in which she also refers to 'many other (stories) which I do not much remember' ('plusieurs autres (histoires) dont je ne me souviens pas trop'). ${ }^{44}$ Long before their

42 'Estant encore à la Cour, comme il disoit un jour à Dieu dans sa prière: Seigneur apprenezmoi ce que je dois faire pour me sauver, il entendit une voix qui lui répondit: Arsène fui la compagnie des hommes, \& par ce moyen tu te sauveras. Lorsqu'il fut dans le désert, faisant la mesme prière à Dieu, il entendit encore une voix, qui lui dit: Arsène fui les hommes: garde le silence, \& demeure dans le repos. Car ce sont là les premières choses qu'il faut faire pour se sauver'. Les vies des Saints pères des déserts et de quelques saintes, écrites par des pères de l'Eglise et autres anciens auteurs ecclésiastiques Grecs et Latins, trans. A. d'Andilly, 2 vols. (Paris, Pierre Le Petit: 1647-1653) vol. 2, 151-162 (151).

43 For information about this site, see note 8. Choisy's stories were later elaborated and published as Choisy François-Timoléon de, Histories de piété et de morale par M.L.D.C. (Paris, Estienne: 1710). This edition was reedited the following year: Choisy François-Timoléon de, Les plus beaux événemens de l'histoire sacrée \& de l'historie prophane raportez à la morale par. M. l'Abbé de Choisy (Paris, Estienne: 1711). Seven years later appeared Choisy François-Timoléon de, Histories de piété et de morale par M.L.D.C., 2 vols. (Paris, JeanBaptiste Coignard: 1718). In the inventory of the library at Saint-Cyr, we find references

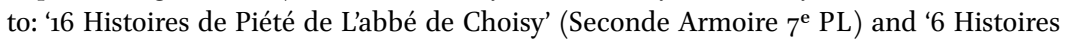
commençant par Esther de Mr de Choisy (Seconde Armoire $7^{\mathrm{e}} \mathrm{PL}$ )', Inventaire des Livres de la Bibliothèque Archive Dép. Yvelines Ms. D 118.

44 Letter from Madame de Maintenon to the Count of Ayen. 4 March [1702] in Madame de Maintenon, Lettres de Madame de Maintenon, 11 vols. (Paris: 2009-2018) vol. 3 (2011), 352-353. In her letter, Maintenon mentions stories about Esther, Clotilde, Saint Arsenius as well as the life of David. The earliest known versions of Choisy's pious stories are two undated, anonymous collections, simply titled Histoires de piété. These collections comprise stories about Placidus, Queen Clotide of France, Paul of Thebes, Queen Elizabeth of Portugal, Alexius of Rome and Saint Arsenius. In one of the manuscripts, the following 
publication, Choisy's stories circulated within this communal setting. According to Preyat's meticulous reconstruction of the editorial process, a number of the stories, including the one on Saint Arsenius, may have been finished in $1692 .{ }^{45}$ If this holds true, Choisy wrote his short account of Saint Arsenius the same year as he translated the Imitatio.

We should here notice that Choisy, in his written account, explains the Saint's withdrawal from the world by reference to courtly intrigues. In response, Saint Arsenius turns to God and, in his most intimate recess, a divine voice answers his prayers: 'Flee, Arsenius, flee the company of men and you will find heaven' ('Fui, Arsene, fui les hommes \& tu trouveras le Ciel'). ${ }^{46}$ Choisy seems less interested in the story of the Saint's second act of withdrawal, which moves him from a coenobitic space, situated in the desert, to a more complete solitude. ${ }^{47}$ Rather the abbot focuses on his position at court and the drama that made him leave it behind. According to his vita, the Saint took flight from a courtly setting where he, according to legend, had served as a princely tutor at the court of Theodosius the Great (347-395). A book lying open in the lower left corner of the image [Fig. 13.3] may point towards Arsenius' role at court, where he was renowned for his great knowledge and rhetorical skill. But the book, left in the lower left, also refers to that from which the Saint flees in search of an insight that runs deeper than the worldly knowledge that he already masters.

Famously, the first book of the Imitatio opens with a meditation on 'Vanitas vanitatum et omnia vanitas' ('Vanity of vanities! All is vanity' Ecc 1.2), which includes reference to the desert saints. ${ }^{48}$ The saint fleeing the world is thus an illustration of the theme of the first book: running out of an open door, the image of the Saint serves as a doorway into the Imitatio. On one level, the door thus belongs to a scene narrated in the life of Saint Arsenius - that is, the very moment when he leaves the court. Simultaneously, the architectural structure

inscription is found: 'Donated by Madame to the infirmary of the community, on the 26th of December, the day of Saint Stephen, 1695' ('Donné par Madame de à l'infirmerie de la communauté le 26 de Décembre jour de saint Estienne 1695'), Historié de piété BnF Ms. Y2-42516 Unpag. This refers to the infirmary at Saint-Cyr.

45 Preyat F., "L'histoire à Madame la duchesse de Bourgogne", in Preyat F. (ed.), MarieAdélä̈de de Savoie (1685-1712). Duchesse de Bourgogne, enfant terrible de Versailles (Bruxelles: 2014) 76-82.

46 Choisy, Histories de piété et de morale (1710) 437-438.

47 In passing, Choisy mentions this second withdrawal as the result of the Saint's holiness and not as a divine command, cf. Choisy, Histories de piété et de morale (1710) 441-442.

48 See Choisy, De l'imitation de Jésus-Christ $35^{-3} 3$. This theme attracted special attention in early modern France: see, e.g., Surin Jean-Joseph, Les Fondements de la vie spirituelle tirés du livre de l'Imitation de Jésus Christ (Paris, Claude Cramoisy: 1667), cf. Le Brun J., Le pouvoir d'abdiquer. Essai sur la déchéance volontaire (Paris: 2009) 73-77. 
represents the reader's entry into the book. This use of an architectonical edifice was common in the early modern period, indicating, in visual terms, that the reader has arrived at the threshold of the book. In this respect, the depiction of the Saint's withdrawal from the world [Fig. 13.3] serves a purpose similar to that of the frontispiece [Fig. 13.2]. Both images visualize a step from the outside to the inside: the figure on the elevated peak figuring the cognitive state that reading requires; the fleeing Saint Arsenius figuring the first step on a path that leads to a sacramental union with Christ. ${ }^{49}$

The gesturing angel in the depiction of the Saint supports this interpretation. Arsenius looks towards this heavenly being, his arms raised as if terrified by its presence, although no such angelic appearance seems to occur in, e.g., Choisy's narrative of the Saint's life. We are thus intended 'to see' what is 'told' - that is, to see the divine voice speaking in the figure of the angel, and, as sound, having an overwhelming effect upon Arsenius. This impact of the divine is caught in the Saint's dramatic gestures and in the movements of his clothing. Almost casually leaning on a cloud, the angel points with its right hand down towards the Saint, while its left gestures away from the built environment. Inside the actual print, the angel's gesture is made on the verso page, while the recto page shows the title of the book: 'DE L'IMITATION DE JESUS-CHRIST'. Following the implied line from the angel's finger, the readerviewer is directed towards the first page of the physical book.

49 In the early modern period, Jesuit authors outlined a link between the four books of the Imitatio and Pseudo-Dionysius schema of purgation, illumination and union. To mention just one example, Martin de Funes (1560-1611) argued for a strong connection between the four books and the phases of meditation. He identifies the act of purgation to the first book and the second book, while the state of union takes place in the final book and its focus on the Eucharist. However, Funes struggles to identify the second phase in meditation, because the illumination of the soul is the subject matter of the entire work and therefore resists univocal identification with any specific part of the text; Funes Martin de, Methodus Practica Aurei Libelli Thomae de Kempis de Imitatione Christi:In Qua Docetur Homo A principio perfectionis Christianae usque ad summum gradum ordinate progredi, tam Magistris, quam Discipulis vitae spiritualis perutilis (Cologne, Anton Hierat: 1590), cf. De Backer A. - Sommervogel C., Bibliothèque de la Compagnie de Jésus, 12 vols. (Paris: 1890-1932) vol. 3 (1893), 1067. A French translation was a permanent appendix to Marillac's immensely popular translation, cf. L'Imitation de Jesus Christ divisez en 4. Livres composez par Thomas a Kempis chanoine regulier et nouvellement mis en françois par M.R.G.A. Avec uune [sic] Methode pour lire avec fruict les livres de l'imitation de Jesus-Christ (Paris, Claude I Calleville: ${ }^{4} 1630$ ). Following the Pseudo-Dionysius schema, Saint Arsenius fleeing court [Fig. 13.3] visualizes the act of purgation, while Saint Louis receiving the Last Rites [Fig. 13.6] depicts the state of union. Below, we shall suggest how the remaining plates might be fitted into the meditative schema. 
On this reading, the gesturing angel, the book and the architectonical artifice serve a purpose that is comparable to the frontispiece [Fig. 13.2]: these elements structure Saint Arsenius' movement away from court, making it into a visual instruction to the reader-viewer. The depicted book in the lower left corner refers to the vanity of worldly knowledge, and the angel's gesture commands the reader-viewer to leave that vain knowledge behind. On the brink of reading the first sentences of Choisy's translation, the angel and the book encapsulate the readers' liminal position: they are about to enter the book and engage with the act of reading, and this engagement opens by leaving the terrestrial world behind. As Choisy informs the dedicatee, courtly glorification of the king's image distorts his sight line. Producing himself in the imitation of Christ, this glorification will be rendered void, and the royal perspective will be restored. Saint Arsenius fleeing court [Fig. 13.3] chimes with this restoration of sight. It shows an escape from court, which the king, of course, is not to literally perform, but rather to imitate. Accordingly, the visual instruction of the frontispiece is slightly different from the instruction visualized by Saint Arsenius fleeing court. The frontispiece [Fig. 13.2] depicts a univocal, cognitive attention to the cross, but also the injunction to produce images and thereby imitate Christ. On a more concrete level, Saint Arsenius instructs the readerviewer about an aspect of the imitation of Christ - that is, the act of purgation and withdrawal from the world. The saintly escape visualizes this mode of imitation. Arsenius depicts Christ's movement away from the world.

\section{The Absent Crown}

A number of motifs repeat in the four images that preface each of the four books in Choisy's translation [Figs. 13.3-13.6]. Most immediately, the act of royal genuflexion connects the image of Louis XIV and the final plate, an image of Louis IX. Christ's presence is signalled in both images, not as a represented figure but through the everlasting light of the altar lamp [Fig. 13.1] and the power of absolution manifested in the confessor's hand [Fig. 13.6]. As the first and last scenes, these two images portray union with Christ in terms of sacraments and their liturgies. Unlike the frontispiece [Fig. 13.2] and Saint Arsenius fleeing court [Fig. 13.3], the appearance of the sacred involves no direct intrusion of the divine: the altar lamp and the confessor's hand point to this appearance, but without, directly, figuring it within the spatio-temporal outline of the plates. Furthermore, the depictions of Louis XIV and Louis IX represent the mystical union as a lived experience: the first unfolds in the historical 'now', while the last scene, like Saint Arsenius fleeing court, unfolds in 
the historical past. As we have seen, Choisy connects the sacramental presence with royal humility. Indeed, the "Epître" to Choisy's La Vie de Saint Louis repeats the connection. Saint Louis 'has made visible' ('a fait voir') that it is possible to combine the throne with the saintliness of the Gospel: in the image of his predecessor, Louis XIV is to see that a king can perform the humility of penitence without compromising the position of royal dignity. ${ }^{50}$

The image of Louis IX [Fig. 13.6] has a Latin inscription at the top and its French translation at the bottom: 'Qui manducat hunc panem vivet in aeternum / Celuy qui mange ce Pain vivra Eternellement' ('Whoever eats this bread will live forever', $J n$ 6.59). The Latin quotation is written on a banderol in the upper middle of the scene, with each of its sides trailing into the frame and its rectangular centre protruding into the depicted scene. The French translation of the Latin is to be found in a cartouche placed in the lower middle of the image. A closed helmet sits on top of the cartouche, where a display of spears surrounds it; the bottom of the cartouche folds around the 'frame' and, like the banderol, occupies a space between inside and outside. The biblical verse thus hovers above and below and slightly in front of the depicted scene that unfolds in front of the crusader's tent.

In turn, $J n 6.59$ is closely related to the assemblage of biblical quotations that open the last part of the Imitatio. In Choisy's translation, the first chapter of the fourth book is titled 'Avec quel respect il faut recevoir JESUS-CHRIST' ('The reverence with which one has to receive Jesus Christ') and opens on a combination of five biblical verses: $M t 11.28$, Jn 6.51, 1 Cor 11.24, Jn 6.56, and Jn $6.63 .{ }^{51}$ Together, these verses encourage the soul, because they speak of sweetness and love. At the same time, however, they also intimidate. Approaching the great mystery at the altar- the corpus mysticum- the soul's unclean conscience causes pain: the sweetness of the words draws the soul in, while man's many vices pull him away from the sacramental mystery. ${ }^{52}$ The presence of Christ at the altar thus prompts mixed emotions: it appeals and repels the soul, placing man's interior between being drawn in and pushed away.

50 Choisy, Vie de Saint Louis Unpag. [3]. In the Cour sainte (1624), Nicolas Caussin (1583-1651) had evoked the Saint King as the perfect example of the 'vita mixta'. For the Jesuits' promotion of Saint Louis in texts, sermons, paintings, chapels, and other media, see Lavieille G., "Les Jésuites et la dévotion à saint Louis au XVII e siècle: la célébration du Roi très chrétien", Les Cahiers de Framespa 11 (2012); Tietz M., "Saint Louis Roi Chrétien: Un mythe de la mission intérieure du XVII Siècle", in La conversion au XVII ${ }^{e}$ siècle, Actes du XII ${ }^{\mathrm{e}}$ Colloque de Marseille (Marseille: 1983) 56-69 (63).

$5^{1}$ Choisy, De l'imitation de Jésus-Christ 273-281 (273-4).

52 Choisy, De l'imitation de Jésus-Christ 274. 
The material elements of the Eucharist, once consecrated, had long been held to be a nourishment for the soul; following a long tradition of commentary, the consecrated elements produce affective states, which, subsequently, manifest themselves in virtuous actions. For this transformation of the votive's states and actions to take place, a strict adhesion to a sequence of gestures was required: these manifest an appropriate respect for the divine mystery. In this respect, the act of genuflexion is one in a larger sequence of movements whereby the priest imitates the actions of Christ, and the community of believers, in their turn, imitate the actions of the priest. The act of genuflexion, as carried out by the celebrant, can thus be interpreted as a restaging of Christ's humility as expressed, for instance, in the Agony in the Garden. ${ }^{53}$ In addition, the priest's initial act of prostration is no veneration for the altar or its representational programme; it is the outward manifestation of his interior movement towards the divine mystery that takes place on the altar. ${ }^{54}$ Without denying either the visual elements of the Mass or the sacerdotal priesthood, ${ }^{55}$ the fourth book of the Imitatio focuses on such inwardness. Prayers during the elevation are templates for an interior spirituality. Human speech and the material forms of the Eucharist prompt a silent mode of contemplation. In the offer to the sinner to commune with the body of Christ, the mystery surpasses all human reasoning, and the heart remains blind, if it refrains from silently contemplating what cannot be represented; God being given to the sinner. ${ }^{56}$

As figurations of such contemplation, the Imitatio invokes Noah, Moses, David and Solomon. In its contemplative state, the soul should emulate, for instance, the hard and lengthy effort involved in creating the Ark, the Ark of the Covenant, and the Holy of Holies in the Temple. Mindful of these efforts, the soul should ask itself in a fictitious monologue: how can I, within the span of a single hour, prepare myself for receiving the one who created the world; why is it hard for me to allocate just a half hour to prepare for this divine presence?57

53 See Le Clerc Sébastian, Tableaux ou sont representees la passion de NS Jesus Christ et les actions du Prestre a la S. Messe. Avec des prieres correspondantes aux Tableaux (Metz, C. Bouchard: 1685) Unpag. [3-4].

54 See, e.g., Molin Louis, Prattique des Ceremonies de la Sainte Messe Selon l'usage Romain (Lyon, Horace Huguetan: 1658) Art. II, v, 5, cf. Le Clerc, Tableaux Unpag. [5-6].

55 Cf. Choisy, De l'imitation de Jésus-Christ 292-294.

$5^{6}$ Choisy, De l'imitation de Jésus-Christ 279-80. In its own context, the Imitatio's emphasis on contemplation of the invisible was a reaction to a strong veneration of the consecrated Host in late medieval Eucharistic devotion: we might here recall the Feast of the Corpus Christi and its institution in the first half of the 14th century. 
The gift of grace thus requires humility and the abnegation of self. ${ }^{58}$ In this line of argument, the Imitatio also invokes individuals who travel far to visit the relics of the Saints. Reading the stories of the Saints' achievements, these individuals, in their own lives, seek out saintly remains: reading turns into visual adoration, and in that moment, the past is made present. ${ }^{59}$

In Choisy's translation, the depiction of Louis Ix [Fig. 13.6] shows the Saint King far away from his homeland: Louis IX is depicted as crusader, thus manifesting an exceptional mode of penitence. Moreover, the king's (failed) attempt to conquer the Holy Land and recapture what had been lost points toward the sacramental presence that requires a continual effort of self-sacrifice, which Saint Louis embodies. Indeed, Choisy narrates the king's final act as a manifestation of extraordinary strength. In his telling, Louis IX disregards immense bodily pain and, in superhuman manner, moves himself towards the celestial realm.

During his illness, he [Saint Louis] took communion several times, and, as he felt his powers leaving him, he asked for the holy viaticum. Having great difficulty in just raising his own head because he was so weak, Saint Louis, having always his eyes set on his God, lifted himself to his feet and then fell to his knees in order to receive it [the holy viaticum]. 'Do you firmly believe', his confessor asked him, 'that this is the true body of Jesus Christ?' 'Yes,' answered the Saint King, 'and I do not believe it any less than if I saw him as when the Apostles saw him on the day of his Ascension'. Hereafter he asked for the Last Rites and responded to all the prayers of the Church. ${ }^{60}$

Choisy's written account refers to a visual appearance. Narrating a past event, datable to 25 August 1270, the Saint King invokes the 'Ascensio Iesu' as it had been witnessed by the Apostles (Acts 1.9-11). Like this displacement, the verse from the Gospel of John hints to the apotheosis of Saint Louis. This hint is furthered by the crown in the centre of the depiction [Fig. 13.6]. Like the book

$5^{8} \quad$ See Choisy, De l'imitation de Jésus-Christ $322-324$.

59 Choisy, De l'imitation de Jésus-Christ 278.

6o 'Il [Louis] communia plusieurs fois pendant sa maladie, \& sentant que les forces commençoient à lui manquer, il demanda le saint Viatique. A peine pouvoit-il lever la tête tant il étoit foible, \& toutefois à la vuë de son Dieu il se leva tout seul, \& se mit à genoux pour le recevoir. Croyez-vous fermement, lui dit son Confesseur, que ce soit là le vrai Corps de JESUS-CHRIST, ouï, répondit le Saint Roi, \& je ne le croirois pas mieux, quand je le verrois tel que les Apôtres le virent le jour de son Ascension. Il demande ensuite l'Extrême-Onction, \& répondit à toutes les prières de l'Eglise'. Choisy, La vie de Saint Louis 141-142. 
left behind by Saint Arsenius [Fig. 13.3], the abandoned crown, partially hidden behind the helmet, refers not simply to the historical scene, but also prompts the reader-viewers to reconsider what they see. The image shows Louis's crown and helmet, positioned in close proximity: these objects are tokens of visible superioritas, which the king's kneeling gesture seems to contradict; we see the monarch defeated, humiliated and turned into a mere mortal. However, the biblical quotation, hovering over the scene, calls this reading into question. About to receive the body of Christ, Louis IX 'will live forever' (Jn 6.59). The 'vivet in aeternum' thus prompts a reconfiguration of royal demise. In a manner similar to the book in the image of the Saint Arsenius, the crown refers to the worldly status that the Saint leaves behind, but it also invites us to imagine what is not depicted: the Saint's apotheosis. In early modern representations, Louis IX's crown was an important visual device: saintliness was manifested by the king receiving the crown of thorns and leaving the regalia behind. ${ }^{61}$ This celestial crowning is not figured in spatio-temporal terms, but inscribed, visually, by the biblical citation. Like in the depiction of Louis XIV [Fig. 13.1], the mystical presence of Christ in the Sacrament invites us to see more in the kneeling, dying figure of the king. He is no mere mortal, subject to the entropy of existence; he embodies a divine order of things.

\section{The Interior Domain}

Taking one further step in the analysis, we should notice how Saint Arsenius's movement is represented as unfolding in the transition from a built to a natural environment: the male figure runs from an architectural structure into the desert [Fig. 13.3]. Under open skies, Saint Louis [Fig. 13.6] kneels to receive the sacrament of the Last Rites: his action conjoins the earthly and the heavenly realms. Moreover, both Saints are in movement, actively taking steps away from the world and towards the heavenly realm. The male figure, in motion, frames the depiction of Mme de Maintenon at the Church of Saint-Cyr [Fig. 13.4] and the visualization of the biblical theme of Christ in the home of Mary and Martha [Fig. 13.5]. Visually, a set of black curtains connects these plates: the fabric hangs in the upper left of the depiction of the church at Saint-Cyr and in

61 This theme appeared in paintings and in the illustrations that accompanied the highly influential poem Saint Louys, ou la Sainte Couronne reconquise (1653) by Pierre Le Moyne (1602-1672). On these illustrations, see Meyer V., "Lillustration du Saint Louis du Père Le Moyne", Cahiers de l'Association internationale des études françaises 57 (2005) 47-73. 
the upper right in the depiction of the home of Mary and Martha. Together, the two images open a window into built interiors, where female figures listen to the divine voice. The negotiation of inside and outside complicates these plates and their otherwise realistic settings; they figure the soul. ${ }^{62}$

Before we can make this claim good, we should first remark that the kneeling figure of Maintenon [Fig. 13.4] serves a purpose similar to the image prefacing Choisy's "Epître" [Fig. 13.1]. Each of the two images anchors Choisy's translation into specific settings. Like the scene from Versailles, the church room at Saint-Cyr is immediately recognizableand both sites were consecrated to Saint Louis and the Virgin. The church at Saint-Cyr had two raised apses, separating the 'chœur' from the 'avant-chœur', where the novices and postulants participated in the liturgical celebrations. ${ }^{63}$ Between the high altar and the choir, the 'église du dehors' served the public. An elaborate 'grille' closed the choir off from this public space. ${ }^{64}$ This structure is not included in the depiction. In fact, the choir appears almost in miniature. Originally, this vast space was equipped with four rows of four benches [Fig. 13.7]. The sixteen pieces of furniture were reserved for the 'demoiselles', ${ }^{65}$ who were educated at the royal foundation by the Ladies of Saint Louis. The image in Choisy's translation shows one of these four rows of benches [Fig. 13.4]. Behind them and at the furthest distance from the 'église du dehors', the Ladies of Saint Louis sat in choir stalls: the antiphonal psalmody could be performed between two groups of thirteen Ladies, each seated on each side of the choir and immediately below the two apses [Fig. 13.7] ${ }^{66}$ In the image from Choisy's translation, we see no such stalls. Turned in ' $\mathrm{L}$-shaped configurations, they would have been visible from the vantage point, where the female figure has fallen to her knees.

62 Following the Pseudo-Dionysius schema of purgation, illumination and union (see note 49), the connection between the two plates, visually manifested by the black curtains, allows for us to allocate both to the phase of illumination and thus make the tripartite schema fit: the male Saints represent purgation and union respectively, while the female figures represent the soul's illumination.

63 In the following, we refer to the architectural plan of the ground level and its explication in Manseau Pierre Gabriel, Les Mémoires de la fondation et communauté royale de Saint Louis. Establie à saint Cyr près Versailles par Louis le Grand, 3 vols. BmV. Mss. G. 351-53, vol. 1, 189-205. The plans are inserted between pages 205 and 206.

64 Manseau, Les Mémoires vol. 1, 191.

65 The 'demoiselles' entered at the age of seven and left ten to thirteen years later. They were divided into colour-coded bands, referring to their age and allocating them to specific classrooms, libraries, and dormitories. Manseau identifies each bench as 'les bancs des bleues' (seventeen to twenty year-olds), 'celuy des jaunes' (fourteen to sixteen year-olds), 'celuy des vertes' (eleven to thirteen year-olds) and 'celuy des rouges' (seven to ten yearolds), cf. Manseau, Les Mémoires vol. 1, 192.

66 Manseau, Les Mémoires vol. 1, 192. 


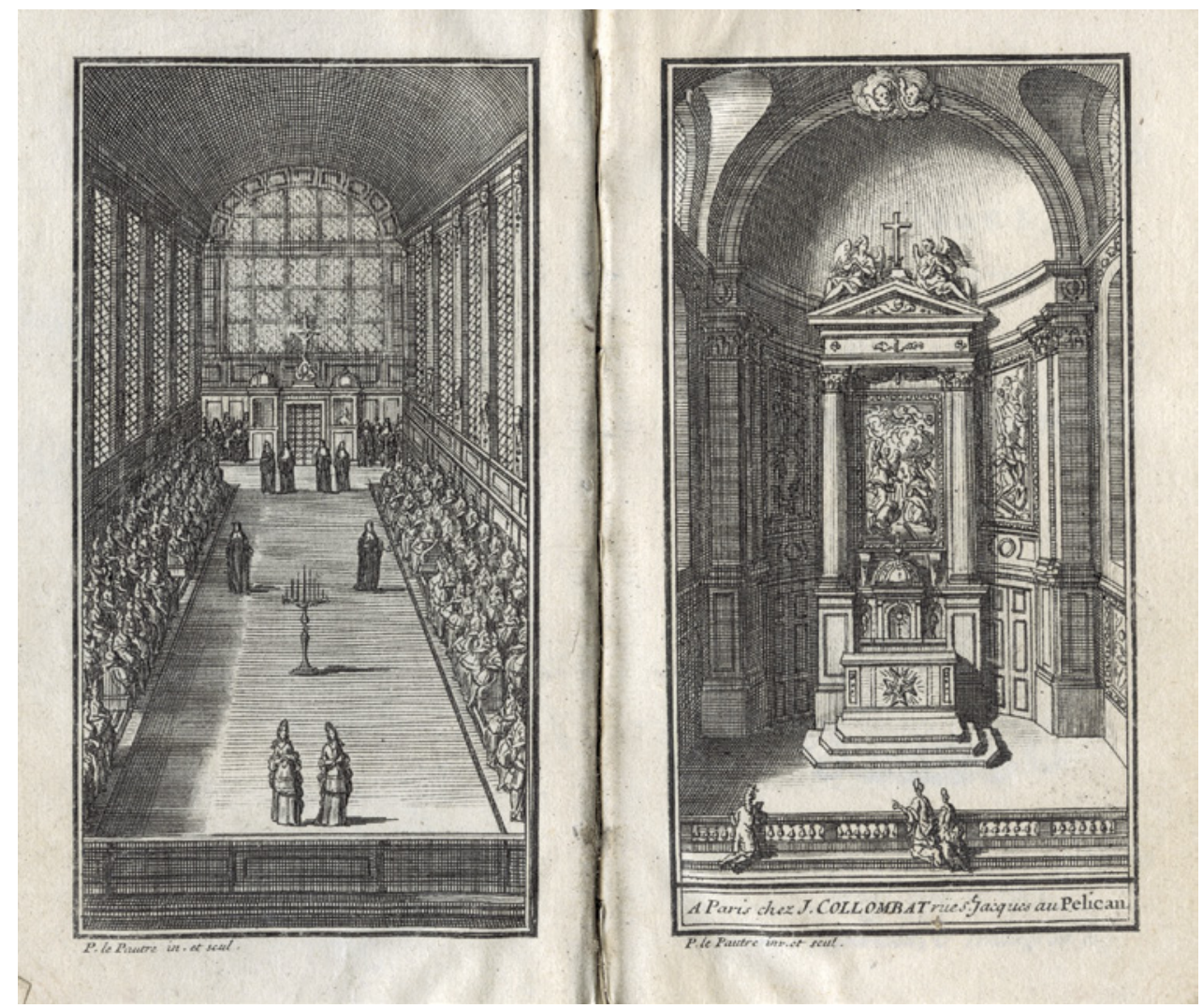

FIgURE 13.7 Le Pautre, "The Church Room at Saint-Cyr", Heures, prières et offices à l'usage et devotion particulièrement des demoiselles de la Maison Royale de saint Louis à Saint-Cyr (Paris, Jacques Collombat: 1714)

(C) LARS CYRIL NøRGAARD

The realistic placement of Maintenon in a convent setting evokes her reputation as a devout 'Queen without a crown'. In fact, the figure's black habit suggests to us that she is a Lady of Saint Louis, while her elevated position distances her from the community, making persuasive the identification with Maintenon. More precisely, the figure is situated in one of the two lodges where the king, his wife, and their guests could participate in the community's liturgical celebrations. The realistic setting is displaced by a cloud formation that appears above the choir with a light shining forth. In letters reversed, two words from Ps. 44.11 can be seen: 'Audi Filia' ('Hear, O daughter', Ps 45.10). Unlike the depiction of Saint Louis and the hovering presence of $J n 6.59$, the biblical inscription is here integrated into the scene. We should not neglect, however, 
that the individuals seated in the choir seem not to notice the divine voice. The 'Filia/ ma Fille' is in the singular: the voice is addressing the individual in the royal lodge, not the girls seated in the choir. Addressed in the singular, the female figure is thus separated in space and by hearing the divine voice. In response, the king's wife, situated above the choir, has fallen to her knees in front of a prie-dieu upon which an open book rests.

The deep background shows the high altar of Saint-Cyr [Fig. 13.4], but the semi-circular apse remains concealed behind, first, the black curtain and, second, an additional cloud formation. Not visible in this image is therefore the altarpiece, created by Jean Jouvenet (1644-1717) and representing the Annunciation. ${ }^{67}$ The view from Maintenon's lodge, situated in the left bottom of the choir, would certainly have included Jouvenet's painting. This absence may led us to reconsider the clouds above the choir and inside the sanctuary. Above the choir, this formation represents the appearance of the sacred: the two words single out the female figure in her lodge. Unlike this intrusion of the divine speech, it is not immediately clear, why there is a second cloud hanging in the background. Why include this ephemeral substance?

\section{8}

\section{Annunciations}

Clouds play a central role in Jouvenet's altarpiece and its visualization of the Incarnation [Fig. 13.8]. Hovering between solid and liquid, the cloud is a metaphor for representing this mystery; it is an amorphous substance oscillating between different states. Jouvenet also has Gabriel moving towards Mary on a cloud rising from the lower left corner, while God the Father, in the upper half of the image, leans down towards the Virgin from another cloud formation. Indeed, this substance takes up much of the scene: the viewer has to work to discern the concrete setting, where the Angel visits the Virgin. Returning to the depiction of Mme de Maintenon at the Church of Saint-Cyr [Fig. 13.4], we might claim that a significant part of the altarpiece - the clouds - has

67 On Jouvenet's altarpiece, see Schnapper A., Jean Jouvenet, 1644-1717, et la peinture d'histoire à Paris (Paris: 1974) $85-88 ; n^{\circ} 35,190$. The painting survives at La Fléche, where it has been since 1816. The original painting was framed by depictions of Saint Louis and the Virgin, cf. Manseau, Les Mémoires vol. 1, 189-190. These paintings remain unknown, but can still be detected see Fig. 13.7. 


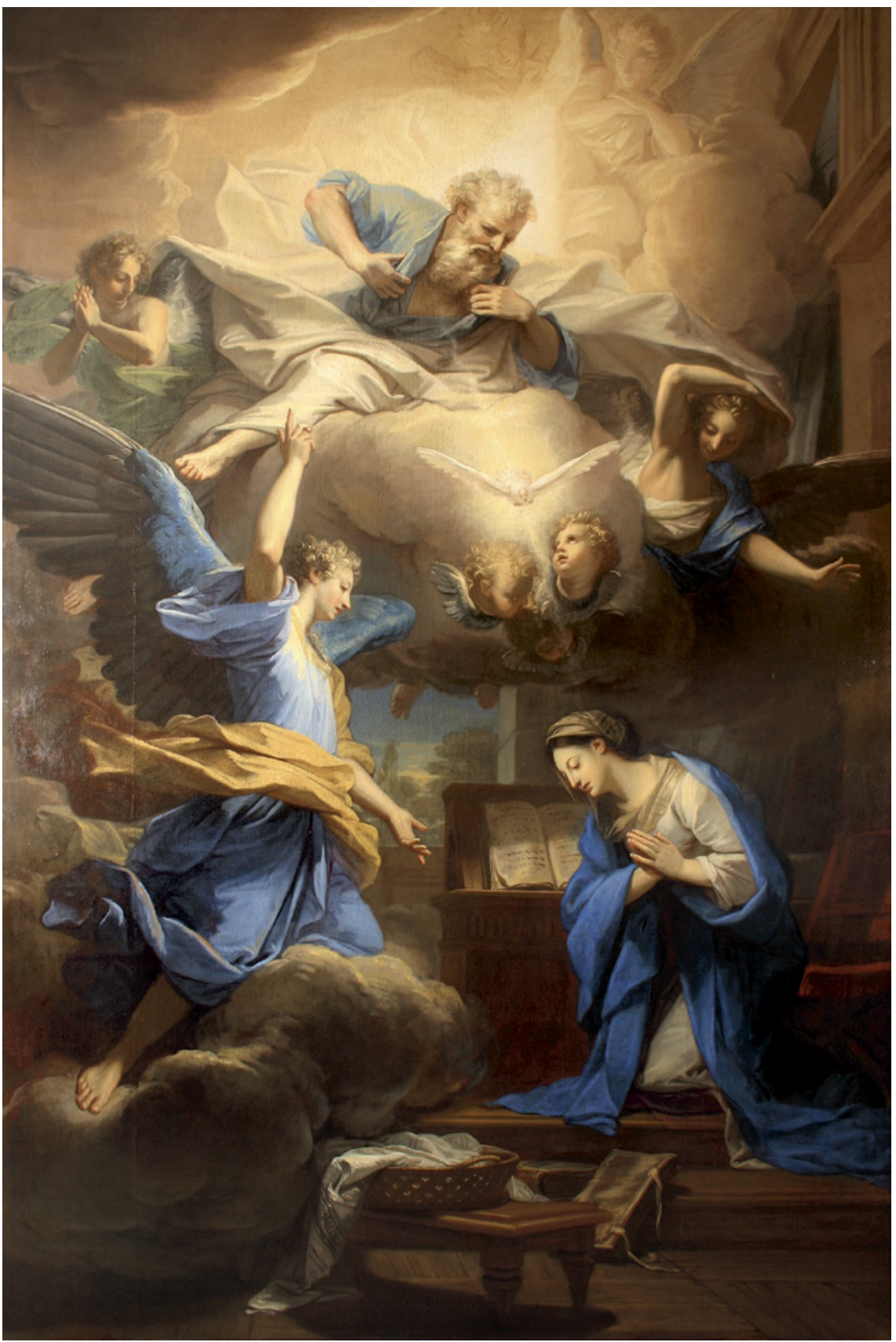

FIGURE 13.8 Jouvenet, L'Annonciation, painted for the chapel of Saint-Cyr (1687), oil on canvas, $309 \times 204 \mathrm{~cm}$

(C) PHOTO COURTESY OF PATRICK BUTI, CONSERVATOR, MUSÉES DE VENDÉE 
separated itself from its framing, taken on a life of its own, and floated into its physical surroundings. With the removal of the altarpiece from the space of representation, something nevertheless remains, and this indivisible remainder evokes the mystery of the Incarnation as impossible to represent.

In the Lucan account of the Annunciation ( $L k 1.26-38),{ }^{68}$ the act of overshadowing plays an important role: 'et respondens angelus dixit ei Spiritus Sanctus superveniet in te et virtus Altissimi obumbrabit tibi ideoque et quod nascetur sanctum vocabitur Filius Dei' ('The angel said to her, The Holy Spirit will come upon you, and the power of the Most High will overshadow you; therefore the child to be born will be holy; he will be called Son of God', $L k$ 1.35). Having the Spirit supervene upon her and, hereby, being overshadowed by divine power, Gabriel explains to Mary what is about to take place. Jouvenet's altarpiece visualizes this angelic explanation and, specifically, obumbrare. Above the Angel and the Virgin, God the Father appears in a cloud formation and reveals, from his chest, a light beam that connects to the Virgin. Along this translucent line, a white dove descends: God overshadows Mary, and the Spirit descends upon her.

In the biblical account, these events are located in the future. Already Gabriel's initial announcement ( $L k 1.31)$ is a citation of the prophet Isaiah (Is 7.14). The angelic message thus detaches itself from the setting wherein it is pronounced, journeying from the protagonists in dialogue to the sacred text, to its representation of the voice of a past prophet, and, thereby, to a past voice that made statements about the future in accordance with God's revelation. Rendering the sequence of events temporally complex, the Angel embodies the voice of a past prophet, while, simultaneously, locating his prophecy in the immediate future. In Jouvenet's painting, a number of mundane objects refer to this conflation of past and future. In the lower middle of the painting, a linen basket rests on a footstool, while an open book sits on a prie-dieu. The book, evidence of Mary's interrupted reading, reminds the viewer that the birth of Jesus was foreseen in the Old Testament, while the basket of linen refers at once to the birth of Christ and the basket of Moses (Ex 2.1-10) in which he floated in the river and, as such, the basket evokes Noah's Ark (Gen 6-9). Like

68 The research literature on the Annunciation is vast. In the following, I mainly draw inspiration from: Marin L., "Logique du secret et représentation de peinture: sur quelques Annonciations Toscanes à la renaissance", in Falassi A. (ed.), La Cifra e l'immagine. Rappresentazioni del segreto nella cultura toscana (Siena: 1988) 57-84. 
the open book and the basket in Jouvenet's painting, the Angel's words to Mary collapse the distinction between the past and the future: they create a connection between what has been and what will come; the Incarnation becomes a prefigured future.

In response to Gabriel's prophecy of the descending Spirit and God's overshadowing power, the Virgin replies: 'Here am I, the servant of the Lord; let it be with me according to your word' ( $L k 1.38)$. Within the biblical narrative, this closing statement - expressed in the present tense ('fiat mihi' / let it be with me') - refers back to Mary's question about the impossible future ('Quomodo fiet istud'/ 'How can this be?', $L k$ 1.34). These juxtapositions of past and present, of prophecy and present realization, give a kind of impetus to the Angel's statement, nearly bringing it into realization: echoing the 'fiat lux' of Creation (Gen 1.3), the Virgin's final utterance is almost a speech act, bringing the mystery closer to realization. This performativity is visualized by Jouvenet as the Virgin has left her chair and fallen to her knees: Mary's bodily gesture of humility and obedience [Fig. 13.9] makes the impossible event of the Incarnation come into closer contact with the present.

Indeed, Jouvenet's composition further elaborates this complex nexus of prophecy, embodiment of pure virtue, and Incarnation. In the middle ground, where the Angel gestures towards the Virgin, his left palm opens into the shared space of communication. In the middle of this horizontal axis, a window opens into a natural setting with trees and a dawning sky. The principal line of sight, receding into the hole of the window, grants 'depth' to the space and situates Mary inside a built environment. Above this vanishing point, where depicted objects are condensed and, as such, disappear out of view, the 'invisible' realm breaks through. Gabriel's right hand deictically refers us to this third party alluded to in the dialogue between Gabriel and Mary: a translucent line materializes this vertical axis and connects the kneeling figure of Mary with God the Father.

In Choisy's translation, the cloud formation in the background [Fig. 13.4] evokes the 'missing' altarpiece and its depiction of the event of the Incarnation. Furthermore, the reader-viewer may have connected the kneeling figure of Maintenon with Jouvenet's painted representation of the kneeling Virgin [Fig. 13.9]. With open right hand and a left that seemingly reaches out for her priedieu, the figure of Maintenon is overwhelmed by the appearance of the sacred. The cloud formation in the foreground and its divine message would seem to trouble her. Connecting Maintenon to Mary through their shared gesture, Maintenon's distress then evokes Mary's startled response to Gabriel's initial salutation (Lk 1.28-29). Indeed, the 'Audi Filia' was the 'tractus' for the Feast of the Annunciation (25 March), and here the nuptial Ps 44 precisely echoes 


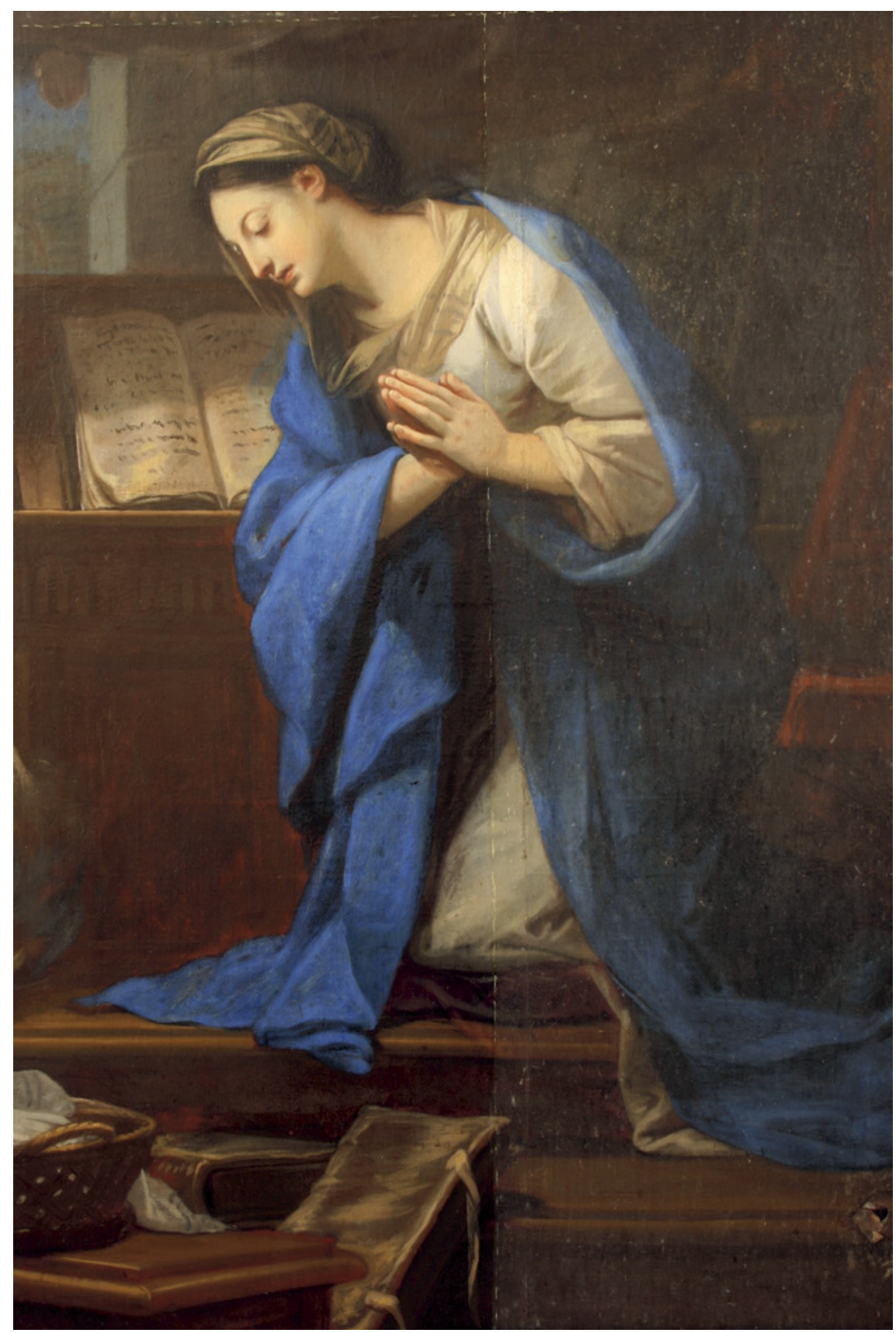

FIGURE 13.9 Jouvenet, L'Annonciation, painted for the chapel of Saint-Cyr (1687), Oil on canvas, $309 \times 204 \mathrm{~cm}$. Detail.

(C) PHOto COURTESY OF PATRICK BUTI, CONSERVATOR, MUSÉES DE VENDÉE 
the Angel's initial salutation. ${ }^{69}$ Following this interpretation and sidestepping speculations on courtly scandal, Mme de Maintenon simulates the pose of the Virgin: the king's wife, in her private space, reiterates Mary's interior response to Gabriel's initial salutation. Unlike the male Saints and their actions [Fig. 13.3 and Fig. 13.6], the female figure and her placement [Fig. 13.4] represent an interior state. In the guise of Mary, the king's wife does not take action in response to the mystical appearance of the sacred; she finds herself in a passionate state, struggling to maintain a grip on reality.

Like the Annunciation, the story of Christ at the home of Mary and Martha is to be found uniquely in the Gospel of Luke $(L k 10.38-42)$. The two plates [Figs. 13.4-13.5] thus present scenes from the same Gospel, ornamented with quotations from $P s 44$ and $P s$ 84, respectively. Furthermore, the image of Mme de Maintenon in the Church of Saint-Cyr [Fig. 13.4] visualizes the imperative to listen ('Audi Filia'). In response, the following plate [Fig. 13.5] carries the biblical verse from Ps 84.9 'Audiam quid loquatur in me Dominus' ('I will listen to what the Lord will say in me', Ps 85.8). In the first scene, God is the grammatical subject of audire; in the second scene, the speaker is the female figure kneeling at the feet of Jesus. First, a heavenly voice speaks, demanding to be heard. Second, the female figure 'speaks', affirming her obedience in listening to what the Lord will teach. Connecting these two plates, the sacred is an interior dialogue between the soul and the divine: visually, the black curtain supports this connection and makes the two images into depictions of stages in the same dialogical exchange.

As in the depiction of Mme de Maintenon, the positioning of Mary in the foreground distances and separates her from the rest of the scene. Jesus sits on the floor with his left foot showing on a step. Below him, Mary rests her back against the elevated floor and gazes at Jesus, almost as if in ecstasy; her hands are crossed in focused meditation. Looking down and returning her gaze, Jesus shows his open left palm, while his right index finger points upwards. Around his head, a halo appears with radiant beams, supporting the transcendent authority of his teachings. Mary listens to the Lord, while Martha has turned her back to Jesus, distracted by worldly commitments. These female figures

69 For Saint-Cyr, this use in the celebration of the Annunciation can be found in, e.g., the gradual by Guillaume Gabriel Nivers (1632-1714), see his: Graduel (1685-1691?) BnF. Dép. Musique Ms. Res F-1374 f. 98-99. 
represent the vita contemplativa and the vita activa, respectively. ${ }^{70}$ By measuring out the distance between the two figures, images and texts represent different levels of withdrawal from and engagement in the world. The story of Mary and Martha posits a vision of the soul on a continuum between two extremes at the one end, meditation and love ('amor') of God or, on the other, charitable actions and love ('dilectio') of the neighbour. ${ }^{71}$ The relationship between the two figures is therefore no opposition, but instead a progression from a worldly state towards an otherworldly state, designated as the contemplative life.

In this light, the in me from $P s 84$ becomes important. In its French translation, the plate renders the entire verse: 'J'ecouteray ce que le Seigneur me dira au fonds du cœur' ('I will listen to what the Lord will say in the very core of my heart'). The act of listening is here clearly located in the interior, both spatially and metaphorically. The image thus represents the soul, when it, univocally, directs itself towards the Word (Mary in the foreground) and not towards the world (Martha in the background). Indeed, the first chapter of the third book of the Imitatio is titled 'On the interior conversation between Jesus Christ and the faithful soul' and opens on the same verse from Ps 84.9. ${ }^{72}$ The depiction relates directly to the part of the book, which it prefaces. Moreover, the third part of the Imitatio is structured as a dialogue between 'the faithful soul' ('l'âme fidèle') and Christ. The opening chapter praises the soul that listens inwardly and from the mouth of the Lord receives words of consolation. In the detailing of this state of interior listening, the ears of the soul are singled out: they hear the sounds of a divine language and close themselves off to the noises of the world. This mode of listening is even more praiseworthy when the same ears, actively not hearing exterior voices, have no other focus than the truth that instructs them in the interior realm ('si négligeant les voix du dehors, elles n'ont d'attention, qu'à la verité que les enseigne au dedans'). ${ }^{73}$ In like manner, the eyes are praised as having the ability to make choices: to be blind to exterior things, so that they see nothing but what moves the soul.

As argued above, Mme de Maintenon is depicted in the guise of the Virgin as she, initially, is troubled by the Angel's words [Fig. 13.4]. At the feet of Jesus,

70 For an overview of the rich history of interpretation of the tension between Martha's charitable engagement and Mary's meditative withdrawal, see Constable G., Three Studies in Medieval Religious and Social Thought (Cambridge: 1995) 1-142. Within the monastic tradition, this tension relates to the difference between 'otium' and 'negotium', cf. Leclercq J., Otia monastica: études sur le vocabulaire de la contemplation au moyen âge, Studia Anselmiana 51 (Rome: 1963) 27-34.

71 Constable, Three Studies 46.

72 See Choisy, De l'imitation de Jésus-Christ 111.

73 See Choisy, De l'imitation de Jésus-Christ 112. 
Mary Magdalen overcomes this initial trouble: unlike Martha, she obediently listens to the Word [Fig. 13.5]. This development takes place in the soul's interior realm, and the plates thus figure two different stages in illumination. Within the visual itinerary of the four prefatory plates [Figs. 13.3-13.6], these two stages in listening make possible a union with Christ [Fig. 13.6], while they, first, require a preceding act of purgation [Fig. 13.3]. Becoming an image of Christ, each of these phases parcels out the reader-viewers and their road to a life in resemblance of Christ, whose life the Imitatio paints as the perfect image of God's will.

The Imitatio makes Christ appear. According to Choisy's words, this appearance tears at the very fabric of court society, revealing flattery as false imagery. This negative thrust invites the dedicatee to see the emptiness of worldly splendour and inscribes humility into his royal interior. This inscription allows Choisy to interpret political opposition as a divine test: by humiliating him in public, God in fact targets Louis in private. This personal sphere is, however, not immediately accessible. Princely privacy remains mysterious. Nevertheless, Choisy maintains that privacy has a profound, albeit hidden impact upon political events. To further this argument, Choisy points to the liturgical situation, where Louis XIV participates in the celebration of the Eucharist. Here, royal humility comes to the fore, and the vignette shows one such public display [Fig. 13.1]. In tandem, word and image support the interlacing of hidden humility and visible actions: the mystical body, in a sacramental sense, is paralleled by the king's mystical person and by that person's political implications.

With reference to this overlap between what remains hidden and what is revealed, the frontispiece evokes God's revelation on Mount Sinai and the Crucifixion [Fig. 13.2]. Following my interpretation, this plate, rather than depicting either of these scenes, invites the reader-viewer to construe an unforeseen scene. The inspection of the cross is a process, wherein readers create themselves in the image of Christ, the true image of God. The following plates are, in this sense, the outcome of a creative process of imagining Christ [Figs. 13.3-13.6]. First, the depictions of Saint Arsenius fleeing court [Fig. 13.3] and of Saint Louis receiving the Last Rites [Fig. 13.6] mark the beginning and the end of this process. Mediating between these extremes, the images of Mme de Maintenon in the Church of Saint-Cyr [Fig. 13.4] and Christ in the home of Mary and Martha [Fig. 13.5] present the soul's illumination in figurative and spatio-temporal terms. As an image of the divine will, the life of Christ, 
encapsulated by the cross, prompts the production of images that visualize different stages in spiritual progression.

In this light, the depiction of Maintenon might have caused courtly scandal, but its main objective seems much subtler than mere provocation. Like the visual overlap between the kneeling figures of Louis XIV and Saint Louis, the king's wife is depicted in the guise of another. In implicit parallel to the Annunciation, the reader-viewer is encouraged to see much more in the kneeling figure of Maintenon: this historical person represents the soul's initial incomprehension of the mysterious appearance. Together with the depiction of Mary and Martha, these images visualize stages in the spiritual progression of the reader-viewer who engages with Christ as the ultimate model. The images in Choisy's translation anchor the sacred in specific settings and in historical individuals, attaching the imitation of Christ to a lifelike or, better, a living image. Besides the obvious and important political configurations of the corpus mysticum, these images transport the mysterious into history, making the two realms continually pass over into each other without ever being completely reconciled.

\section{Selective Bibliography}

Barbier F., “Quelque observation sur les origines d'un succès européen”, in Delaveau M. Sordet Y. (eds.), Édition et diffusion de l'imitation de Jésus-Christ (1470-180o), Études et catalogue collectif (Paris: 2011) 35-51.

Choisy François-Timoléon de, Interpretation des Pseaumes, où les differences notables de l'hebreu \& de la Vulgate sont marquées. Avec la vie de David (Paris, Antoine Dezaillier: 1687).

Choisy François-Timoléon de, La Vie de Salomon (Paris, Claude Barbin: 1687).

Choisy François-Timoléon de, Vie de Saint Louis (Paris, Claude Barbin: 1689).

Choisy François-Timoléon de, Histoire de Charles cinquième, roi de France (Paris, Antoine Dezaillier: 1689).

Choisy François-Timoléon de, Historie de Charles VI, Roi de France (Paris, J.-B. Coignard: 1695).

Choisy François-Timoléon de, Histories de piété et de morale par M.L.D.C. (Paris, Estienne: 1710).

Le Clerc Sébastian., Tableaux ou sont representees la passion de NS Jesus Christ et les actions du Prestre a la S. Messe. Avec des prieres correspondantes aux Tableaux (Metz, C. Bouchard: 1657; third ed. Metz, C. Bouchard: 1685).

Constable G., Three Studies in Medieval Religious and Social Thought (Cambridge: 1995). Van der Cruysse D., Labbé de Choisy. Androgyne et mandarin (Paris: 1995). 
Van der Cruysse D., "L'abbé de Choisy et le mythe louis-quatorzien", in De Branche en Branche. Études sur le XVII et le XVIII e siècles français, La République des lettres 26 (Louvain: 2005) 213-223.

Delaveau M., "Les traductions française de l'imitation de Jésus-Christ au XVII e siècle. Étude d'ensemble et présentation de deux best-sellers illustrés", in Bodemann U. Staubach N. (eds.), Aus dem Winkel in die Welt. Die Bücher des Thomas von Kempen und ihre Schicksale (Frankfurt am Main: 2006) 80-99.

Gouzi C., "Louis XIV en Saint Louis: une autre image de la figure royale", in Da Vinha M. - Maral A. - Milovanovic N. (eds.), Louis XIV l'image et le mythe (Rennes: 2014) $57-70$.

Von Habsburg M., Catholic and Protestant Translations of the Imitatio Christi 1425-1650 (Farnham-Burlington: 2011).

Kantorowicz E., The King's Two Bodies: A Study in Mediaeval Political Theology (Princeton: 1957).

Thomas à Kempis, L'Imitation de Jesus Christ divisez en 4. Livres composez par Thomas a Kempis chanoine regulier et nouvellement mis en françois par M.R.G.A. Avec uune [sic] Methode pour lire avec fruict les livres de l'imitation de Jesus-Christ, Paris: Claude I Calleville: ${ }^{4} 1630$ ).

Thomas à Kempis, De l'imitation de Jésus-Christ. Traduction Nouvelle, trans. FrançoisTimoléon de Choisy (Paris, Antoine Dezallier: 1692).

Thomas à Kempis, De l'imitation de Jésus-Christ. Traduction Nouvelle. Dediée au roi, trans. François-Timoléon de Choisy, fourth edition (Paris, Antoine Dezallier: 1699).

Lavieille G., "Les Jésuites et la dévotion à saint Louis au XVII e siècle: la célébration du Roi très chrétien", Les Cahiers de Framespa 11 (2012).

Leclercq J., Otia monastica: études sur le vocabulaire de la contemplation au moyen âge, Studia Anselmiana 51 (Rome: 1963).

Maral A., "Portrait Religieux de Louis XIV", Dix-septième siècle 217 (2002/4) 697-723.

Marin L., Le portrait du roi (Paris: 1981).

Marin L., "Logique du secret et représentation de peinture: sur quelques Annonciations Toscanes à la renaissance", in Falassi A. (ed.), La Cifra e l'immagine. Rappresentazioni del segreto nella cultura toscana (Siena: 1988) 57-84.

Meyer V., "L'illustration du Saint Louis du Père Le Moyne", Cahiers de l'Association internationale des études françaises 57 (2005) 47-73.

Meyer V., "Suites et cycles: les éditions illustrées de l'Imitation de Jésus-Christ au XVII Siècle”, Édition et diffusion de l'imitation de Jésus-Christ (1470-180o), Études et catalogue collectif (Paris: 2011) 53-70.

Neveu B., "Du culte de Saint Louis à la glorification de Louis XIV: la maison royale de Saint-Cyr", Journal des savants 3 (1988) 277-290.

Preyat F., Le Petit Concile de Bossuet et la christianisation des moeurs et des pratiques littéraires sous Louis XIV (Berlin: 2007). 
Preyat F., "L'histoire à Madame la duchesse de Bourgogne", in Preyay F. (ed.), MarieAdélaïde de Savoie (1685-1712). Duchesse de Bourgogne, enfant terrible de Versailles (Bruxelles: 2014) 58-85.

Schnapper A., Jean Jouvenet, 1644-1717, et la peinture d'histoire à Paris (Paris: 1974).

Sordet Y., "Formes éditoriales et usages de L'Imitatio Christi, XV ${ }^{\mathrm{e}}-\mathrm{XIX}{ }^{\mathrm{e}}$ siècles", Comptes rendus des séances de l'Académie des inscriptions et belles-lettres 2 (2012) 869-895.

Tietz M., "Saint Louis Roi Chrétien: Un mythe de la mission intérieure du XVII Siècle”, in La conversion au XVII ${ }^{e}$ siècle, Actes du XII' Colloque de Marseille (Marseille: 1983) 56-69. 